\title{
A Proposal for the Resolution of Systemically Important Assets and Liabilities: The Case of the Repo Market*
}

\author{
Viral V. Acharya, ${ }^{a}$ and T. Sabri Öncü ${ }^{\mathrm{b}}$ \\ ${ }^{a}$ New York University Stern School of Business, NBER, and CEPR \\ ${ }^{\mathrm{b}}$ Centre for Advanced Financial Research and Learning, Reserve Bank \\ of India and New York University Stern School of Business
}

One of the several regulatory failures behind the global financial crisis that started in 2007 has been the regulatory focus on individual, rather than systemic, risk of financial institutions. Focusing on systemically important assets and liabilities (SIALs) rather than individual financial institutions, we propose a set of resolution mechanisms, which is not only capable of inducing market discipline and mitigating moral hazard but also of addressing the associated systemic risk, for instance, due to the risk of fire sales of collateral assets. Furthermore, because of our focus on SIALs, our proposed resolution mechanisms would be easier to implement at the global level compared with mechanisms that operate at the level of individual institutional forms. We, then, outline how our approach can be specialized to the repo market and propose a repo resolution authority for reforming this market.

JEL Codes: G01, G18, G21, G28.

\footnotetext{
${ }^{*}$ This article was prepared for the Board of Governors of the Federal Reserve System's research conference on "Central Banking: Before, During, and After the Crisis," held on March 23-24, 2012, in honor of Don Kohn. The authors are deeply indebted to Barry Adler, Nouriel Roubini, and Matt Richardson for collaborations and discussions on earlier work on the issue of resolution mechanisms for systemically important financial firms. The authors are also grateful for discussions on the issues of safe harbor for repo contracts and repo-market-related systemic risks with Rocco Huang, Antoine Martin, Enrico Perotti, and Mark Roe, and comments from discussants (Andrew Crockett and Ricardo Caballero) and participants at the Federal Reserve Board conference. Last, but not least, we would like to thank George Kaufman for bringing the Glass proposal to our attention. Author e-mails: vacharya@stern.nyu.edu; Sabrioncu.cafral@rbi.org.in.
} 


\section{Introduction}

Systemic risk can be defined broadly as the expected losses from the risk that the failure of a significant part of the financial sector leads to a reduction in credit availability with the potential for adversely affecting the real economy. ${ }^{1}$ There are at least two contesting views on the causes of systemic risk. In the so-called microprudential view, the systemic risk arises from contagion of the failure of a financial institution to the rest of the financial sector. As short-term creditors of an institution demand immediacy against its long-term assets ("run"), short-term creditors of interconnected or similar institutions may demand such immediacy too. In contrast, in the so-called macroprudential view, the systemic risk arises from the collective failure of many financial institutions because of their common risk-factor exposures. In this view, when short-term creditors of an institution demand immediacy against long-term assets, there is a disruptive run only if other institutions are unable to acquire the long-term assets at fair values; in particular, if institutions have correlated exposures, then other institutions are potentially facing runs too and assets must be sold at fire-sale prices, resulting in disorderly liquidations, potential allocation inefficiencies, and a general increase in the rate of return on savings (which can induce hoarding behavior and cut back on real-sector lending).

Although these two views are not mutually exclusive, much of the regulatory reforms take one view or the other. In the microprudential regulations, the focus is on the systemically important financial institutions (SIFIs) whereas in the macroprudential regulations, the focus is (also) on the risk of a crisis in the financial sector and its spillover to the economy at large. Taking the microprudential view, both the Dodd-Frank Wall Street Regulation and Consumer Protection Act (DFA) signed into law by President Obama in July 2010 in the United States and, internationally, Basel III focus on single financial institutions.

SIFIs consist of financial intermediaries that include not only commercial banks taking deposits and making loans but also investment banks, money-market funds, mutual funds, insurance firms,

\footnotetext{
${ }^{1}$ This definition is based on Acharya, Pedersen et al. (2010). See, for example, Kaufman and Scott (2003) for other definitions.
} 
and potentially even hedge funds, whose failure poses a systemic risk to the financial system. This systemic risk can come through multiple forms, which include counterparty risk on other financial institutions, asset liquidations that can produce a depressing effect on asset prices, liquidity hoarding that raises funding costs in interbank markets even for safe firms, and an information contagion effect resulting in a significant reduction in overall market liquidity. Therefore, any mechanism set up by the regulators to deal with the insolvency of SIFIs must follow at least four basic principles (Acharya, Adler et al. 2010):

(i) The counterparty risk of the SIFIs must be contained through regulations including the imposition of capital requirements, margin rules, and limitation on risky investments ex ante.

(ii) There needs to be a procedure for dealing with large amounts of illiquid assets whose forced sales can have a catastrophic effect on the financial system.

(iii) The resolution mechanism should be able to identify insolvent institutions promptly, as they can become pockets where financial resources of the economy can get trapped, potentially creating funding problems even for otherwise solvent firms.

(iv) There must be well-defined rules for what happens to the liabilities of the financial institution when it fails, for otherwise a run on most of the institution's liabilities will occur, potentially leading to a systemwide run.

Furthermore, since many SIFIs operate across borders (global SIFIs, or G-SIFIs) and, as we have witnessed in the recent financial crisis, their failure can threaten the integrity of the entire global financial system, to the above four principles we must add the following:

(v) The national resolution mechanisms should be amenable to easy international coordination for the effective resolution of G-SIFIs.

When the collapse or near collapse of such financial institutions as Bear Stearns, Lehman Brothers, AIG, and the like after the onset of the global financial crisis in 2007 made clear the inability of the 
existing resolution mechanisms to deal with the failure of SIFIs, the United States was the first mover with the Dodd-Frank Act. To address the concerns about the inability of the existing resolution mechanisms to handle the failure of SIFIs, Title II of the DFA created the Orderly Liquidation Authority (OLA) as a new mechanism. However, as is stated fairly clearly in Title II of the DFA, the OLA is not a resolution but a liquidation mechanism. ${ }^{2}$

Putting aside the question of whether such a liquidation - rather than a resolution - authority focusing on individual financial institutions is sufficient to achieve the DFA-stated goals of inducing market discipline and mitigating moral hazard, the question of whether the OLA can address the systemic risk associated with such systemically important markets as the sale and repurchase agreement ("repo") market or such systemically important sectors of small institutions as the money-market mutual funds remains debatable. ${ }^{3}$ Although we discuss our concerns regarding the OLA in detail in the next section in detail, let us give the following simple example from September 2008 to illustrate how the OLA may fail in containing the systemic risk.

After Lehman Brothers filed bankruptcy on September 15, 2008, its outstanding debt collapsed in price almost immediately. Since one of the largest money-market mutual funds (MMMFs), the Reserve Primary Fund, was highly exposed to Lehman Brothers' collapsing short-term debt, its net asset value (NAV) fell below par the next day. Since MMMFs offer stable NAV and investors can redeem anytime at par, an immediate run on the Reserve Primary Fund occurred, causing it to shut down. This failure opened up the possibility that other MMMFs were similarly exposed, and a run on the MMMFs started. Since MMMFs are a primary source for the commercial paper market, this run opened up the possibility of capital shortfalls at many financial institutions that needed to roll over commercial paper. Only after the government guaranteed the MMMF deposits 100 percent did the run come to a halt and the slide stopped.

${ }^{2}$ Title II, Orderly Liquidation Authority, HR 4173, Sec. 204, "Orderly Liquidation of Covered Financial Companies."

${ }^{3}$ See Acharya, Adler et al. (2010) and Acharya et al. (2011) for detailed discussions. 
Under the OLA, if invoked as described in Title II of the DFA, the Reserve Primary Fund would have been placed into a receivership administered by the Federal Deposit Insurance Corporation (FDIC) to be liquidated (assuming that the Reserve Primary Fund - or the money-market funds sector as a whole - were deemed systemically important by the Financial Stability Oversight Council, set up under the DFA). Although the FDIC could have borrowed from the Treasury to finance the liquidation, if the proceeds from liquidation were insufficient to repay the Treasury, the FDIC would have had to claw back from creditors any amounts received in excess of what they would have received in an ordinary liquidation. ${ }^{4}$ Given that the investors of MMMFs were offered stable NAV and promised that they could redeem anytime at par, it is evident that a liquidation authority such as the OLA — which with its focus on eliminating the moral hazard associated with the "too-big-to-fail" status recovers from creditors any amounts received in excess of what they would have received in an ordinary liquidation - neither could have nor would have stopped the slide in such an episode. ${ }^{5}$ An orderly liquidation of the assets of the Reserve Primary Fund was not even an issue then. Furthermore, neither was the Reserve Primary Fund "too big to fail" despite its $\$ 64.8$ billion worth of assets prior to its shutdown, nor was it even an SIFI on its own right. What was systemically important in September 2008 was the $\$ 3.5$ trillion financial sector of MMMFs. The intervention had to be done at the sector level to avoid a possible collapse of the entire financial system.

Another problem associated with the OLA is that it does not apply to the foreign subsidiaries of the G-SIFIs. For example, when Lehman Brothers filed for chapter 11 protection in September 2008, this action triggered well over sixty insolvency proceedings worldwide, some of which were particularly harmful to global financial stability (Acharya, Adler, and Richardson 2011). Even if the OLA existed at the time of Lehman Brothers' insolvency, the assets and liabilities of its UK prime brokerage would have been resolved under

\footnotetext{
${ }^{4}$ If there is any remaining shortfall, the FDIC can levy an assessment on all financial companies deemed a SIFI by the involved regulators.

${ }^{5} \mathrm{Had}$ the MMMFs offered floating rather than stable NAV, there might not have been a run on the Reserve Primary Fund, entailing the systemwide run on all MMMFs, of course. However, in such a scenario, all MMMFs would be disintermediated by the bank money-market accounts rapidly.
} 
the UK law. Although in response to the G20 call for action, the Financial Stability Board (FSB) recently issued a new international standard for resolution mechanisms "so that any financial institution, whatever its size and complexity, can be resolved without disruption to the financial system and without taxpayer solvency support," 6 it is still unclear how this new standard will be implemented in the United States and can be reconciled with the OLA.

Furthermore, even the FSB-issued new international standard described in its November 2011 "Key Attributes" document ${ }^{7}$ focuses on individual financial institutions that are to be deemed globally systemically important, that is, G-SIFI. To see why this might be a problem, take, for example, the rehypothecation of hedge funds' assets held at Lehman's UK prime-brokerage unit during Lehman's bankruptcy. Under the UK law (which was changed later), these assets became Lehman's creditors' take. This led not only to runs on hedge funds but also to overall uncertainty about which assets at financial institutions were safe and which were not (Acharya, Adler, and Richardson 2011). No resolution mechanism focusing on G-SIFIs, even if internationally coordinated as described in "Key Attributes," could have worked quickly enough to stop these effects.

Finally, while there were indeed runs on SIFIs in this and previous crises, there was also a large number of collective runs on relatively smaller financial institutions, especially in the so-called shadow banking system, such as on hedge funds, special-purpose vehicles (conduits and structured investment vehicles, or SIVs), and as discussed earlier, money-market funds. For instance, the assetbacked commercial paper (ABCP) run on conduits and SIVs sponsored by commercial banks starting August 8, 2007 (see Acharya, Schnabl, and Suarez 2009) highlights that a collection of small institutions and an entire class of claims or markets can also be systemically important, i.e., their failure can lead to systemwide loss of financial intermediation.

With these in mind and taking the macroprudential view, we propose an alternative set of resolution mechanisms, based on the insights of Acharya, Adler, and Richardson (2011), which is not at

\footnotetext{
${ }^{6}$ See www.financialstabilityboard.org/press/pr_111104dd.pdf.

${ }^{7}$ See www.financialstabilityboard.org/publications/r_111104bb.pdf.
} 
the level of SIFIs, but at the level of systemically important assets and liabilities (SIALs) of financial institutions, whether these institutions are deemed systemically important or not. Systemically important liabilities (SILs) can be defined broadly as those liabilities of highly leveraged entities that are assets of other highly leveraged entities and therefore, when faced with haircuts in case of default, would trigger runs on other entities. Examples of SILs include deposits, repos, and over-the-counter (OTC) derivatives. Similarly, systemically important assets (SIAs) can be defined broadly as those assets that are either SILs of other highly leveraged entities or potentially illiquid, high-risk assets financed through SILs. Examples of SIAs include exposures to SIFIs, asset-backed commercial paper, and risky repo collaterals such as mortgage-backed securities (MBS). To the extent possible, the set of mechanisms should be expanded to cover as many classes of systemically important assets and liabilities as possible. ${ }^{8}$

What we propose is that instead of attempting regulation of systemically important financial institutions (a "top-down" approach to regulating systemically important assets and liabilities), prudential regulation should be built in the form of a "bottom-up" approachone that works at the level of the SIALs rather than at the level of the SIFI that owns them. Under the "bottom-up" approach there would be an automatic stabilizer built for each SIAL. The automatic stabilizers could be in the form of government-provided but appropriately charged deposit insurance, centrally cleared SIALs with initial and variation margins or haircuts charged by a clearinghouse or dedicated resolution authority for those SIALs, and, in extreme cases, lender of last resort from the central bank against eligible assets (but to avoid moral hazard, only to firms that pay a market-rate fee). This way, when a SIFI fails, it is not the orderly resolution of an individual SIFI that has to be effected, but rather the resolution of its various SIALs; the parts of its capital structure that are not systemically important would be resolved by market-determined contracts and relevant bankruptcy procedures. A particularly attractive feature of the "bottom-up" approach is that it requires no uniform institutionlevel insolvency process and therefore might be the simplest way

${ }^{8}$ A detailed discussion of our approach, originally proposed by Acharya, Adler, and Richardson (2011), can be found in their document. 
of achieving international agreement on resolving the financial distress of G-SIFIs (as long as there is global agreement on resolution mechanisms for SIALs).

We present as a leading example of our approach the systemically important assets and liabilities underlying the repo market and propose a potential repo resolution authority for reforming the repo market to illustrate how our approach can be implemented for this particular class of SIALs. ${ }^{9}$ A repurchase agreement-also known as a "sale and repurchase agreement," or more popularly as a repois a short-term transaction between two parties in which one party borrows cash from the other by pledging a financial security as collateral. One important feature of the U.S. repo market is that all transactions that fall under the umbrella of repos are exempt from the automatic stay in bankruptcy, and therefore all repo transactions can be liquidated following a bankruptcy filing. As is well known, the ongoing global financial crisis was triggered in the summer of 2007 essentially by a "run" on two Bear Stearns hedge funds speculating in potentially illiquid subprime mortgages by borrowing short term in the U.S. repo market and eventually on Bear Stearns in March of 2008. We describe these "repo bank runs" and the role the fire-sale liquidation of the repo collaterals - that are exempt from the automatic stay - played in the ensuing systemic crisis (in section 3.2 in detail).

Our proposal for resolving repo runs is to create a "repo resolution authority" in each jurisdiction with significant repo transactions. The repo collaterals will in general not be exempt from bankruptcy of borrowing financial firms, except when the collateral is in the form of highest-quality government or governmentguaranteed bonds. All other repo collateral on defaulting repo transactions will be resolved by the repo resolution authority, which makes an immediate "liquidity" payment to repo financiers. The immediate payment is based on conservative assumptions (a "haircut") about the liquidation proceeds from the collateral. The realized proceeds will in general exceed or be smaller than the conservative payment and will be repatriated or clawed back from repo financiers. In the process, however, the repo resolution authority takes on the

\footnotetext{
${ }^{9}$ The proposal and discussion to follow elaborate on the initial case the authors made in Acharya and Öncü (2010).
} 
credit risk of the repo financiers. To manage this credit risk and to attenuate the moral hazard induced on the part of repo financiers, the repo resolution authority would include as eligible only relatively high-quality collateral, charge repo financiers an ex ante fee for the liquidity enhancement provided in case of default in a manner that is commensurate with the residual credit risk borne by the facility, require that eligible repo financiers meet prespecified solvency criteria, and impose a concentration limit at the level of individual repo financiers as well as on the financier's overall portfolio size.

In effect, the repo resolution authority does resemble a clearinghouse for repo contracts in that it has the right to suspend automatic conversion of repo claims into liquidations of underlying collateral; it takes on the liquidation rights itself but ensures that its provision of liquidity to the market in case of default does not engender insolvency concerns. The repo financiers, which face participation criteria and haircuts in good times, would pass on the relevant costs to borrowers in the repo markets. Collateral that is not eligible for the repo resolution authority would remain outside of bankruptcy exemption as well as outside of the liquidity enhancement provided by the repo resolution authority; these contracts would thus be relatively subordinated in the capital structure of financial firms and they could be subject to prudential capital requirements or minimum haircut/overcollateralization requirements (as with other parts of the capital structure of financial firms).

An important issue that our proposed resolution approach highlights is that of the desirability of granting unconditional liquidation rights ("safe-harbor" provisions) to certain claims of creditors ("qualified financial contracts") of financial institutions. The advantage of granting such rights is to extend money-like immediacy properties to such claims and enhance the capacity of financial institutions to generate liquidity. The macroprudential view of financial crises highlights, however, that in times of a substantial aggregate shock, the system may be rendered incapable of granting such immediacy to all creditors of financial institutions: not all demandable deposits can be paid off without resorting to bank failures and loss of relationship loans, or not all repo or derivative counterparties can be paid off without engaging in disorderly fire sales and generating associated externalities. 
Indeed, in much the same way that commercial bank clearinghouses in the pre-Federal Reserve era were forced to suspend conversion of immediacy of demandable deposits in order to stem bank runs, our proposal recommends that safe-harbor provisions be conditionally suspended when there has been a sufficiently adverse common shock to the financial institutions. When such systemic exception is invoked on safe-harbor provisions, our resolution approach grants partial immediacy to the affected claims (through the repo resolution authority or the lender of last resort) but suspends immediacy of the remaining part, forcing them to bear longrun risk of the underlying collateral or assets backing the claims. The long-run risk is managed in an orderly manner by such suspension, making it clear that the clearinghouses, repo resolution authorities, and the lender of last resort must also be granted asset-liquidation rights in times of systemic crises. Equally importantly, since management of such risk exposes these authorities to potential losses, they are also granted the rights to contain a priori the extent of immediacy granted by financial firms to their creditors.

We organize the rest of the paper as follows: In section 2, we describe some specific details of the DFA and evaluate it with respect to the efficiency of the process and its ability to mitigate moral hazard and systemic risk. In section 3, we describe how the repo market came to play such an important role in securitized banking in the United States, discuss its critical role in the form of runs in the crisis, and argue a case for reforming the repo market based on our analysis. We then outline in section 4 our proposed "repo resolution authority" for such reform and compare and contrast it with an interesting precedent, the Federal Government Liquidation Corporation proposed by Senator Glass in the early 1930s, in section 5 . Finally, in section 6 , we discuss how our proposed resolution mechanism for the repo market may be coordinated globally and present our concluding remarks.

\section{The Dodd-Frank Resolution Mechanism for Non-Bank SIFIs}

A central objective of the DFA is to create a new resolution mechanism for non-bank SIFIs and bring them within the FDIC insurance model. Established in 1933, the FDIC is an independent federal 
agency of the United States that insures deposits at its member banks and savings and loan institutions, currently up to $\$ 250,000$ per depositor per institution. If a member institution fails, it is taken into receivership by the FDIC, which within a few days either facilitates a merger with another FDIC-insured institution or pays each depositor for the insured portion of their accounts at the closed institution and then liquidates the closed institution's assets. Since the Federal Deposit Insurance Reform Act of 2005 - signed into law by President Bush in February 2006 and effective March 31, 2006-the FDIC finances the liquidations from the Deposit Insurance Fund (DFI), to which member institutions pay an ex ante insurance fee based on the balance of insured deposits, as well as on the FDICassessed risk the institution poses to the DFI. ${ }^{10}$ And, if further funds are needed, the FDIC can draw on a line of credit with the U.S. Treasury. Furthermore, the FDIC deposit insurance is backed by the full faith and credit of the U.S. government, which means that the resources of the U.S. government stand behind FDIC-insured depositors.

According to Sheila Bair (FDIC 2011), the former chair of the FDIC, the DFA resolution mechanism has these basic elements:

- Title I: The establishment of the Financial Stability Oversight Council (FSOC), chaired by the Secretary of the Treasury and comprising members from the other financial regulatory agencies, with the responsibility of designating SIFIs or "covered companies" that will be subject to heightened supervision by the Board of Governors of the Federal Reserve System (FRB).

- Title I: The requirement for the preparation of detailed resolution plans - often referred to as "living wills" - by covered companies to demonstrate that they are resolvable under the bankruptcy laws if they run into severe financial stress and provide valuable advance information that will assist in implementing their orderly liquidation, if necessary.

- Title II: The prohibition of bailouts of individual companies by providing an alternative to bankruptcy with the establishment of an OLA, which allows the FDIC to resolve non-bank

\footnotetext{
${ }^{10}$ For a history prior to 2006 , see www.fdic.gov/deposit/insurance/history.html.
} 
financial companies by using many of the same trustee powers over systemic non-bank financial companies that it has long used to manage failed bank receiverships.

The DFA characterizes non-bank financial companies that can be covered under the OLA quite broadly. The companies eligible for covered financial company ( $\mathrm{CFC}$ ) designation include bank holding companies, non-bank financial companies supervised by the FRB, and any other company predominantly engaged in activities that the FRB determined financial in nature, as well as the U.S. subsidiaries of these eligible companies. However, the DFA resolution mechanism is an iterative process: First comes the attempted resolution as described in the living wills through the bankruptcy code in a manner that "does not pose a systemic risk." If the attempt fails, then follows the "orderly liquidation" under the OLA, presumably avoiding the systemic risk and therefore the "too-big-to-fail" bailout of the SIFIs with the taxpayer funds. Or so goes the theory.

The above is one of the main problems associated with the new DFA resolution mechanism. Under the DFA resolution mechanism, a failed non-bank SIFI goes through normal bankruptcy or other applicable insolvency law first. ${ }^{11}$ Only after the Secretary of the Treasury - upon recommendation by the FRB by a two-thirds vote and a similar vote by the FDIC (or, in some cases, other involved regulators), in consultation with the President - determines that the failed financial company should be subject to OLA, and the board of directors of the CFC approves the Secretary of the Treasury's determination, is the FDIC appointed as receiver of the CFC. Otherwise, the Secretary of the Treasury files a petition with the U.S. District Court for the District of Columbia seeking judicial review of

\footnotetext{
${ }^{11}$ We acknowledge at the outset that our discussion of the OLA is based on the Dodd-Frank Act's "letter of the law," whereas it is clear from its specific implementation that is currently under way that some of the criticisms we raise concerning OLA are being partly addressed. Since the implementation details are still evolving, our presentation of the OLA can be interpreted as a "straw man" representing the microprudential view of resolution authority, rather than simply as a criticism of the Dodd-Frank Act's vision of the OLA. We note, however, that most of the fixes under the OLA's implementation of concerns we raise also operate at the level of individual financial institutions, rather than taking a collective or macroprudential view of the resolution authority (as we propose).
} 
his decision. If the district court finds the Secretary's petition "arbitrary and capricious" within twenty-four hours, then the petition is denied. Otherwise, either through court approval or, if the district court does not make a determination within twenty-four hours of receipt of the petition, through operation of law, the petition is granted and the FDIC is appointed as receiver of the $\mathrm{CFC}$. If the FDIC is appointed as receiver of the CFC either through the first or the second of the above processes, then the board of directors of the CFC - as well as other aggrieved parties - has thirty days to appeal the appointment of the FDIC as receiver.

There are at least two issues with the above: The first issue is that the regulators may wait too long to intervene and have no choice but to put the SIFI through the liquidation process. This is a very risky proposition in terms of systemic risk, as we describe below. The second issue is that, despite the commendable efforts to expedite the liquidation process, the procedure may not be sufficiently fast to contain the ensuing run on liabilities that can be pulled immediately. Because of these uncertainties underlying the OLA process, it is highly likely that the following will occur (Acharya, Adler et al. 2010):

- Runs on these and other short-term liabilities of the institution will occur in anticipation of such determination, creating a self-fulfilling OLA event.

- Holders of the institution's longer-term debt and equity will try to sell their holdings in secondary markets, putting pressure on the financial firm's position in capital markets.

- Runs on similar financial firms may occur, essentially leading to the regulators having no choice but an OLA determination for a significant part of the financial sector.

While any insolvency procedure is subject to these problems, it is unclear how the DFA resolution mechanism will address them through the OLA.

Another problem associated with the DFA resolution mechanism is the Orderly Liquidation Fund (OLF) on which the FDIC will be authorized to draw as the receiver. In the originally proposed bill, this fund was to be financed ex ante by risk-based assessments of the CFCs in such a way that the more systemically important the CFC, the larger the assessment. In the signed law, however, this provision 
was dropped. Instead, the FDIC will borrow from the Treasury and will repay the borrowings from creditors who receive funds in the OLA process that are greater than what they would have received in normal liquidation under the bankruptcy code. And, if this clawback is not sufficient, the FDIC will repay from ex post assessments on bank holding companies with total assets of $\$ 50$ billion or more and on any non-bank SIFI.

Although the FDIC's use of the OLF is discretionary, let us suppose that the FDIC used the OLF to finance the failed CFC as intended by the DFA. That is, the failed CFC is supplied with liquidity, but a portion of its assets - presumably equal in value to the loans extended - is retained for the OLF. However, if the CFC has failed because the value of its assets is less than that of its obligations, unless it is subsidized in receivership, its counterparties will not be paid in full and hence the risk of contagion will remain. Therefore, the OLA might not contain the systemic risk that the failure of a large, interconnected SIFI might undermine the financial system.

Consequently, it might be expected that the FDIC as the receiver will not use the OLF to achieve an orderly liquidation of the assets of the failed CFC, but rather will use it to bail out the failed CFC creditors. That is, to prevent contagion, the FDIC might be expected to satisfy counterparty claims that could not be paid from the assets of the failed CFC even if the assets are liquidated in an "orderly" fashion. This very likely to materialize bailout expectation - a perceived insurance that covers the losses of the creditors - creates moral hazard, the very risk the DFA aims to eliminate.

If, on the other hand, the clawback provision of the OLA is indeed credible and, as a result, the creditors become the de facto insurers, then the DFA would realign incentives, eliminating the potential moral hazard as intended. The question then remains whether the FDIC as the receiver can claw back the moneys paid to creditors in excess of what they would have received in normal liquidation under the bankruptcy code after the "orderly" liquidation. If the perception is that the receiver can, then the bailout will have no effect. Under this scenario, however, as soon as it is remotely perceived that a CFC will be subject to the OLA, a large-scale run on the systemically important liabilities-i.e., SILs of the failed CFC and similar financial institutions - will occur. 
Furthermore, even after ignoring all of the problems discussed above, there remains the question of who picks up the bill if all else fails to repay the Treasury. The DFA answer to this question is the financial industry itself. But the DFA-imposed ex post assessments require that even the prudent financial companies pay for the failure of the others. This would be a problem even from merely an ex post perspective, as the costs to the financial system could be substantial and might weigh against the ability of the system to provide credit, creating an illiquid financial system the DFA is intended to avoid. From an ex ante perspective, the problem is even worse. The DFA plan for even the healthy financial institutions to pay the creditors of failed CFCs creates a free-rider problem. This encourages all financial institutions to take excessive risks, leading to an even more fragile financial system and hence increasing the likelihood of deep financial crises.

Yet another principal difficulty in writing insolvency law for SIFIs is the issue of how to treat their so-called qualified financial contracts (QFCs). In the United States under the current bankruptcy code, QFCs include forwards, swaps, repos, and other OTC derivative contracts, and are essential for the functioning of SIFIs. In fact, what differentiates SIFIs from other financial institutions is essentially their substantial presence in the market for QFCs. The QFCs are related to our notion of systemically important assets and liabilities (SIALs), and whether a QFC is an SIL or SIA depends on the position taken in the QFC as well as on the market conditions. For example, a long position in a call option is an SIA irrespective of the market conditions, while a long position in an interest rate swap - that is, a fixed-payer interest rate swap - may be either an SIL or SIA, depending on the market conditions.

The current U.S. Bankruptcy Code, enacted in 1978, initially provided a safe harbor from automatic stay and other bankruptcy provisions for commodity and forward contracts. In this context, safe harbor means exemption from bankruptcy proceeding, whereas automatic stay means an injunction issued automatically by the bankruptcy court upon the filing of a bankruptcy that prohibits collection against the debtor or the debtor's property. The safeharbor clause allows the counterparty to the failed financial institution to terminate the QFCs and take control of what it is owed from the assets of the failed institution. With the Bankruptcy Abuse 
Prevention and Consumer Protection Act (BAPCPA) enacted in 2005, the safe-harbor exception has been broadly expanded to cover such QFCs as cross-netting provisions, credit default swaps, interest rate swaps, and margin loans, among other arrangements, including repos. We discuss how the BAPCPA reform of 2005 affected the repos in detail in subsequent sections. An excellent discussion of the advantages and disadvantages of the safe-harbor clauses for QFCs can be found in Tuckman (2010), and we briefly review these below. See also Edwards and Morrison (2004), Jackson (2009), Miller (2009), Faubus (2010), and Roe (2010), among others.

The original motivation for the safe-harbor status of the QFCs in the bankruptcy code was to reduce the systemic risk in the financial system. Because most QFCs are either hedged or used as hedges continually, tying up counterparty QFC positions in bankruptcy would unwind the hedges in place and lead to wide-scale risk exposures for leveraged institutions. Moreover, if the underlying collaterals are tied up, the loss in potential liquidity for the counterparty might also have serious consequences. Either of these problems, together with uncertainty about when the failed-institution QFCs would be cleared, could cause the associated markets to freeze. Hence, the safe-harbor status granted to the QFCs has some merit.

However, the reduction in systemic risk arising from QFCs avoiding the automatic stay and related provisions in bankruptcy is replaced by another form of systemic risk involving fire sales of QFCs and funding illiquidity spirals. For example, consider the repo agreements. Many repo financiers are money-market mutual funds (MMMFs) subject to restrictions on average maturity of their investments. When they face default on a repo of a long-term asset such as a mortgage-backed security (MBS), their typically overnight role as a lender in a repo financing gets translated into being the holder of a long-term asset. As a result, the MMMFs as the repo financier may be forced to liquidate the asset upon failure of their repo counterparty. Similarly, counterparties of a failing firm in a derivative contract might need to terminate and replace the contract right away, as it might be serving as a hedge of some financial risk. Then, as counterparties liquidate the repo collateral all at once, or terminate and replace their derivative positions simultaneously, with the large number of trades and multiple participants, money markets and derivatives markets can be destabilized. In the recent crisis, 
there was considerable concern that a bankruptcy of SIFIs like AIG, Merrill Lynch, or Citigroup would have forced large amounts of mortgage-backed derivatives to be sold on the marketplace. Given widespread exposure to these securities by other financial institutions, these losses would have caused a funding liquidity freeze, resulting in even more sales and losses and therefore leading to a death spiral of large parts of the financial system.

An equally strong argument against the safe harbor is the regulatory arbitrage it creates within the system: counterparties can build up large concentrated exposures without much consequence. Specifically, because most QFCs can be engineered to mimic an underlying asset, there exist at least two claims with essentially the same economic behavior. However, these essentially same claims may be subject to different rules and therefore may have different implications for ex ante risks. For example, consider again a repo against an AAA-rated MBS. If the MBS is held on the banking book of a SIFI, it gets treated as a long-term holding subject typically to capital requirement against potential credit risk for a year. If the MBS is instead on the trading book as an available-for-sale security that is being rolled overnight in repo markets, then it gets treated as being sold and repurchased each day, so that as far as its capital requirement is concerned, it is subject to market risk for only one day.

This transformation of a long-term asset into an overnight asset is primarily because of the repo financier's right to take over the asset in the case of failure of the repo counterparty. However, as explained above, in many cases repo financiers themselves cannot own these assets in the long run and must liquidate them upon failure of their repo counterparty. Therefore, the migration of the MBS from the banking to the trading book lowers the capital requirement against it throughout the financial system, since no institution is holding capital for a scenario where there is systemic illiquidity under which some institution - most likely an institution which incurred a huge illiquidity discount in the fire sale of the asset - must hold the asset for the long run.

Such distortions push counterparties toward designing complex products that can help shift assets from the banking to the trading book, which are then financed using short-term repos in the repo market, away from the monitoring of regulators and at substantially 
lower capital requirements. The effective outcome is tremendous liquidity in repo markets for these products in good times, with systemic stress and fragility when the products are anticipated to experience losses. The expansion of safe harbor to repo transactions with underlying mortgage-based assets in the Bankruptcy Act of 2005 has thus been cited as one of the reasons for the growth in mortgage-based derivatives over the period from 2005 to 2007.

The DFA essentially treats QFCs the same way the FDIC treats them in receiverships not covered by the Act. That is, at the end of the first business day after a receivership commences, counterparties would be able to exercise their rights against the CFC such as to terminate, net out, set off, and apply collateral with respect to all their QFCs. Therefore, although the provision of a safe harbor under the DFA is not identical to that of the bankruptcy code, QFCs still benefit from special protection. An exception is that until the end of the first business day after commencement, the FDIC would be allowed to transfer all (and only all) of the QFCs between the $\mathrm{CFC}$ and a given counterparty. Although such exceptions to the safe-harbor clause make some sense to the extent the systemic risk of financial institutions might vary from one situation to the next, a better approach would be (Acharya, Adler, and Richardson 2011) as follows:

- QFCs that are liquid should keep the exemption. Liquid QFCs will cause less systemic risk in fire sales yet still allow counterparties to manage their risk without the uncertainty generated by the bankruptcy of a SIFI. Moreover, in order to get the exemption, counterparties will have an incentive to trade in liquid QFCs.

- QFCs that are illiquid - or potentially illiquid (such as repo contracts on MBSs) - should be subject to the ordinary rules of bankruptcy, including the automatic stay. The systemic risk underlying fire sales would be avoided, especially given that complex, illiquid transactions are more difficult to unwind. Of course, this would come at the cost of general liquidity of the counterparties and impact their ability to manage risk. To the extent regulators impose capital and liquidity standards, QFCs subject to the stay should apply higher liquidity standards to the counterparty. 
Lastly, as we discussed in the previous section at length, the DFA resolution mechanism is completely domestic. This is an important problem because many U.S. SIFIs operate globally, so that they are G-SIFIs. Furthermore, many G-SIFIs incorporated in other countries operate in the United States as well. If a G-SIFI operating in the United States needs to be liquidated in an orderly manner, the DFA cannot specify how its systemically important assets and liabilities (SIALs) in other countries will be resolved. The resolution of G-SIFIs requires an international arrangement. Although the Financial Stability Board - established by the G7 in 1999 and reestablished by the G20 in 2009 to coordinate at the international level the work of national financial authorities and international standard-setting bodies - issued a new international standard for resolution mechanisms in November 2011, as we mentioned earlier, no international resolution mechanism has yet been proposed by any international body. This leaves the global financial system still wide open to significant systemic risk that may result from a disorderly liquidation of SIALs somewhere in the world, thereby requiring "too-big-to-fail" or "too-many-to-fail" or "too-interconnected-to-fail" bailouts of SIFIs everywhere, even if the DFA resolution mechanism manages to avoid a disorderly liquidation of associated U.S.-based SIALs in spite of the problems we pointed out above.

\section{The U.S. Repo Market}

Recall that a repurchase agreement is a short-term transaction between two parties in which one party borrows cash from the other by pledging a financial security as collateral. In a repo transaction, the collateral provider enters into a "sale and repurchase agreement" or, in short, a repo. The cash provider enters into a "purchase and resale agreement," or, in short, a reverse repo. Hence, every repo is also a reverse repo and vice versa. The perspective depends on who is the seller and who is the purchaser.

The day the repo is initiated is called the sale date, and the day the repo is terminated is called the purchase date. The differenceif any-between the values of the collateral and loan is called the "haircut" or margin. The haircut - if any - is a protection against the counterparty risk in the transaction. In principle, either the cash or the collateral provider may be subject to a haircut. When the 
cash provider is subject to a haircut, then the haircut is the margin required by the collateral provider as protection against the potential value gain of the collateral in case the cash provider fails to deliver the collateral on the purchase date so that the collateral provider has to buy a substitute. When the collateral provider is subject to a haircut, then the haircut is the margin required by the cash provider as protection against the potential value loss of the collateral in case the collateral provider fails to come back and the cash provider has to take ownership of the collateral, sell it, and recover the loss.

In the U.S. repo market, loans are mostly extended overnightthat is, they are one-day transactions. Overnight repos constitute about half of all repo transactions, and most of them are open, i.e., they roll over automatically until either party chooses to exit. Other repo transactions, called term repos, have terms longer than one day but shorter than one year, although the vast majority have maturities of three months or less. Participants in the repo market include commercial banks, investment banks, hedge funds, mutual funds, pension funds, money-market funds, municipalities, corporations, and other owners of large amounts of idle cash, as well as the Federal Reserve and primary securities dealers.

The Federal Reserve participates in the repo market mainly to implement its monetary policy; primary securities dealers participate mostly to finance their market-making and risk-management activities. On the other hand, owners of large amounts of idle cash engage in the repo market mainly for two reasons: (i) to get better interest rates in the repo market compared with deposits at commercial banks, and (ii) for insurance purposes; while large deposits at commercial banks are not insured, deposits at "repo banks" are secured by debt used as collateral.

\subsection{Evolution of the U.S. Repo Market}

Repos were introduced to the U.S. financial market by the Federal Reserve in 1917. Repos allowed the Federal Reserve to extend credit to its member banks after a wartime tax on interest payments on commercial paper had made it difficult for banks to raise funds in the commercial paper market. Later in the 1920s, the Federal Reserve Bank of New York used repos secured with bankers' acceptances to extend credit to dealers to encourage the development of a liquid 
secondary market for acceptances. Repos fell from grace during the Great Depression after massive bank failures and low interest rates, only to make a comeback after the Treasury-Federal Reserve Accord of 1951 "that renewed emphasis on controlling inflation rather than keeping interest rates low" (Garbade 2006).

Early repos in the United States had two distinguishing features. First, accrued interest was excluded from the price of the repo securities. Second, even though the creditor could sell or deliver the repo securities to settle a prior sale at prices that included the accrued interest during the term of the repo, ownership of the repo securities rested with the debtor. These features had the following implications: (i) the repo securities were underpriced, (ii) the creditor had to remit to the debtor any coupon payments on the repo securities during the term of the repo, and (iii) in the event of a bankruptcy of the debtor, the repo securities were subject to automatic stay; that is, the creditor could not take ownership of the repo securities and sell them immediately. ${ }^{12}$ These features remained intact until the early 1980s.

During the period of high inflation in the 1970s and early 1980s, rising short-term interest rates made repos a highly attractive shortterm investment to holders of large amounts of idle cash. Increasing numbers of corporations, local and state governments, and - at the encouragement of securities dealers - even school districts and other small creditors started depositing their idle cash in "repo banks" to earn interest rather than depositing money in commercial banks

\footnotetext{
${ }^{12}$ However, there appears to have been some deliberate vagueness about this until a government securities dealer, Lombard-Wall, collapsed in 1982, and the Federal Bankruptcy Court of New York imposed an automatic stay on the repo securities that Lombard-Wall had used as collateral. See www.nytimes.com/1982/12/17/business/lombard-wall.html.

This point had always been uncertain until the 1982 and 1984 amendments to Code 11 of the U.S. Bankruptcy Code. In a "true sale," the buyer is not subject to the automatic stay. For instance, if an automobile dealer bought a car from General Motors the day before it filed for bankruptcy, it could resell the car without asking for permission of the court. However, if the deal were financed by General Motors, the dealer would need a court order to sell the car. The repo transactions are structured formally as a true sale, free of the automatic stay. The question was, and still is, whether courts would reclassify them as secured transactions. Before 1982/4, this would inflict the stay on the collateral taker. After 1982/4, it would only affect the rights of a secured party, which are more limited than the rights of a buyer.
} 


\section{Figure 1. Monthly Averages of Daily Outstanding Overnight and Term Repos, 1970-86}

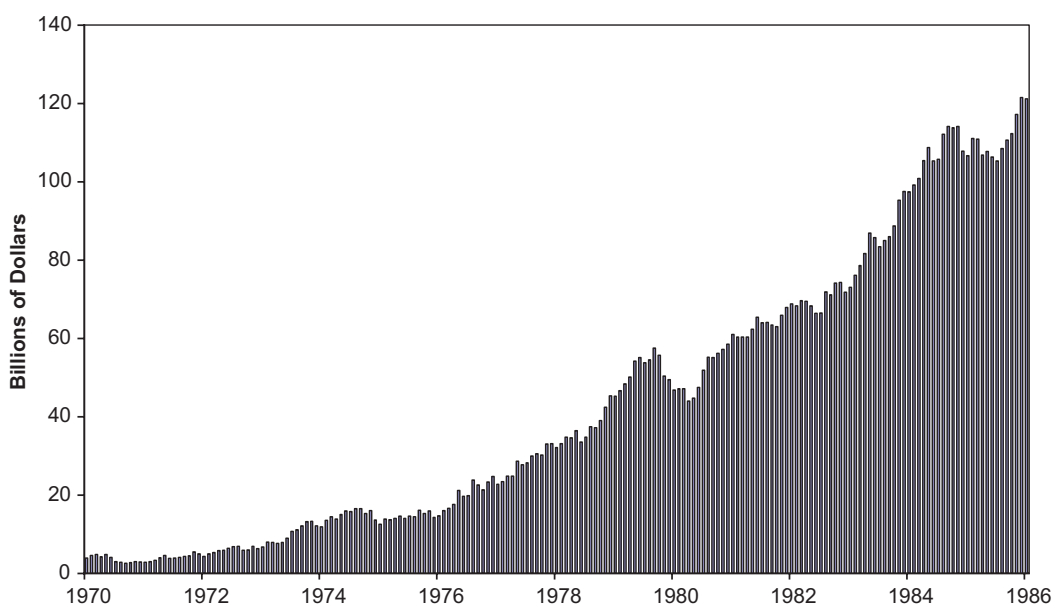

Source: Federal Reserve Board.

that did not pay interest on demand deposits. Furthermore, the U.S. Treasury started borrowing heavily after 1974, eventually changing the status of the United States from a creditor to a debtor nation and increasing the volume of marketable Treasury debt significantly. This led to a parallel growth in government securities dealers' positions and financing, and the repo market grew by leaps and bounds. Figure 1 depicts the size of the market from January 1970 to January 1986, as reported by the Federal Reserve Board.

The first important change to repo contracts came after the spectacular collapse of Drysdale Government Securities Inc. in 1982. Despite its limited equity, Drysdale had been acquiring substantial amounts of debt securities through reverse repos and at prices that excluded the accrued interest. Drysdale then short-sold these securities to third parties at prices that included the accrued interest. Drysdale used the surplus thus generated to raise more capital and to make interest payments to its reverse repo counterparties. However, when interest rates moved against Drysdale in May 1982, the cumulative losses on its interest rate bets depleted its capital. On May 17, 1982, Drysdale failed to pay the interest on the securities it had borrowed. When that news hit the repo market, it came to 
a near halt, forcing the Federal Reserve to intervene as a lender of last resort to calm fears and prevent a collapse. This near collapse exposed the systemic risk associated with the exclusion of accrued interest and, therefore, largely at the encouragement of the Federal Reserve Bank of New York, inclusion of accrued interest in the invoice price of repo securities became standard market practice (for details, see Garbade 2006).

The foundation for the second important change in repo contracts was laid when another government securities dealer, LombardWall, with $\$ 2$ billion in assets and comparable liabilities, collapsed three months later in August 1982. Prior to Lombard-Wall's August 12, 1982, filing with the Federal Bankruptcy Court of New York, there had been no precedent court case in which the question of whether repos were secured loans or independent sale and repurchase agreements was directly addressed. If repos were classified as sale and repurchase agreements, then creditors could take immediate possession of the repo securities; if, on the other hand, they were classified as secured loans, then repo securities would have been subject to automatic stay. On August 17, 1982, the Federal Bankruptcy Court of New York announced that Lombard-Wall's repos were secured loans and issued a restraining order prohibiting the sale of these repo securities. Although submissions by the Federal Reserve Bank of New York and several others argued that this decision would undermine the liquidity of the repo market, the court reaffirmed its decision a month later (Garbade 2006). This removed the vagueness associated with whether repos were secured loans or independent sale and repurchase agreements. Despite this ruling, investment banks, mutual funds, and other large financial institutions favored the exception of repo securities from the application of automatic stay, although they seemed unwilling to write contracts that clearly stated that a repo was a pair of outright sale and repurchase transactions. ${ }^{13}$

Debates continued until another securities dealer, Lion Capital Group, collapsed in May 1984, and a bankruptcy court placed an automatic stay on Lion's repo securities. ${ }^{14}$ Shortly thereafter,

\footnotetext{
${ }^{13}$ Even if they did, a court would be free to reclassify them.

${ }^{14}$ See "Lion Capital's Collapse Raises Issue of Unresolved Legal Status of 'Repos'," Wall Street Journal, May 8, 1984.
} 
Congress ended the debates about the classification of repos by enacting the Bankruptcy Amendments and Federal Judgeship Act of 1984, exempting repos on Treasury and federal agency securities, as well as those on bank certificates of deposit and bankers' acceptances, from the application of automatic stay. Since then, repos on these securities have been exempt from automatic stay.

Dealer delivery failures in the 1980s also gave rise to the emergence of "tri-party repos," in which the counterparties used a third agent, called the tri-party agent, to manage the collateral. The triparty agent ensured that the collateral pledged was sufficient and met eligibility requirements, and all parties agreed to use the collateral prices supplied by the tri-party agent. Today, there are only two tri-party agents in the United States, called the "tri-party clearing banks": the Bank of New York Mellon and JP Morgan Chase. Tri-party repos became popular partly because of these efficiency gains associated with the intermediation role of the clearing banks. Indeed, the efficiency gains, and the fact that so many institutions use the tri-party repo, are among the reasons the Federal Reserve uses the tri-party repo market to implement monetary policy (Copeland, Martin, and Walker 2010). However, because these two clearing banks have a huge amount of exposure on an intraday basis, regulators expressed concerns that fears of the financial health of a major dealer or clearing bank could quickly spread contagion throughout the market. Indeed, the Federal Reserve's decision to extend its lender-of-last-resort support to the systemically important primary dealers during the recent financial crisis through the so-called Primary Dealer Credit Facility (PDCF) was partly a result of these concerns.

The "tri-party settlement" is one of two settlement methods used in the United States. ${ }^{15}$ The other is the "delivery versus payment" (DVP) method. For example, the Federal Reserve's reverse repos are settled via the DVP method, wherein securities are moved against simultaneous payment. The Federal Reserve sends collateral to the clearing bank of its reverse repo counterparty, triggering a simultaneous movement of money against the collateral on the sale date. On the purchase date, the counterparty sends the collateral back

\footnotetext{
${ }^{15}$ See Copeland et al. (2012) for an excellent yet brief overview of the U.S. repo market as of June 25, 2012.
} 
to the Federal Reserve, which triggers the simultaneous return of the counterparty's funds. Such repo transactions are called bilateral repo transactions. Dealers also use DVP repos to obtain funding. However, because DVP repos are not as convenient as tri-party repos, they are believed to represent a small share of dealer funding (Copeland, Martin, and Walker 2010). There is also the GCF Repo ${ }^{\circledR}$ market dealers use to exchange cash and general collateral with each other (Fleming and Garbade 2003), as well as an interdealer repo market for less-liquid collateral (Gorton and Metrick 2009b).

Although the repo market grew rapidly after the Bankruptcy Amendments and Federal Judgeship Act of 1984, until the mid-1990s it remained confined mostly to U.S. government debt, federal agency debt, corporate debt, and federal agency mortgage-backed securities. However, since the mid-1990s, it has grown to include a broad range of debt instruments as collateral: all types of private-label MBS, such as residential mortgage-backed securities (RMBS) and commercial mortgage-backed securities (CMBS); all types of assetbacked securities (ABS), such as automobile loans, credit cards, and student loans; and tranches of structured products such as collateralized mortgage obligations (CMOs), collateralized loan obligations (CLOs), collateralized debt obligations (CDOs), and the like (see Gorton 2009).

The last significant change to the repo contracting conventions came in 2005. In April 2005, Congress enacted the Bankruptcy Abuse Prevention and Consumer Protection Act of 2005 (BAPCPA), which took effect in October 2005. BAPCPA expanded the definition of repurchase agreements to include mortgage loans, mortgagerelated securities, and interest from mortgage loans or mortgagerelated securities. This meant that as of October 2005, repo contracts on even MBS, CMOs, CMBS, and CDOs backed by mortgages and the like as collateral became exempt from automatic stay. We summarize the milestones in the evolution of the U.S. repo market in box 1 .

Furthermore, although repos collateralized by other financial securities such as corporate bonds, municipal loans, and equities are excluded from the bankruptcy code definition of "repurchase agreements" and hence do not qualify for exemption from automatic stay for "repurchase agreements," since they qualify as "securities contracts," they are subject to safe harbor from automatic stay for the 


\section{Box 1. Timeline of Important Events in the U.S. Repo Market}

1917 Federal Reserve introduces repos; accrued interest is excluded from the invoice price of repo securities and repo securities are subject to automatic stay.

1929 Use of repos declines with the onset of the Great Depression.

1951 Congress enacts the Treasury-Federal Reserve Accord of 1951, bringing repos back into favor.

1982 Accrued interest is included in the invoice prices of repo securities.

1984 Congress enacts the Bankruptcy Amendments and Federal Judgeship Act of 1984 to exempt repos on Treasury and federal agency securities, as well as on bank certificates of deposit and bankers' acceptances, from the application of automatic stay.

2005 Congress enacts the Bankruptcy Abuse Prevention and Consumer Protection Act of 2005 to expand the definition of repos to include mortgage loans, mortgage-related securities, or interest from mortgage loans or mortgage securities; all mortgage-related repo securities become exempt from the application of automatic stay.

QFCs discussed in the previous section. To sum up, all transactions that fall under the umbrella of repos will likely be exempt from the automatic stay in bankruptcy either as "repos" or as "securities contracts," and therefore all repo transactions can be liquidated following a bankruptcy filing.

No official statistics of the actual size of the repo market have been collected since inclusion of almost all types of securitized debt as collateral was allowed in repo agreements. Therefore, there is no official information on the evolution of the size of the repo market over the past quarter of a century. Figure 2 depicts the evolution of financing by primary dealers in the U.S. government securities market from 1996 through 2011 and offers a feel for the exponential growth of the repo market since the mid-1990s. Meanwhile, figure 3, reproduced from the Federal Reserve Bank of New York (FRBNY) Task Force on Tri-Party Infrastructure white paper (FRBNY 2010), shows the growth of the tri-party repo market from May 2002 through May 2010. 


\section{Figure 2. Annual Averages of Daily Financing by U.S. Government Securities Primary Dealers}

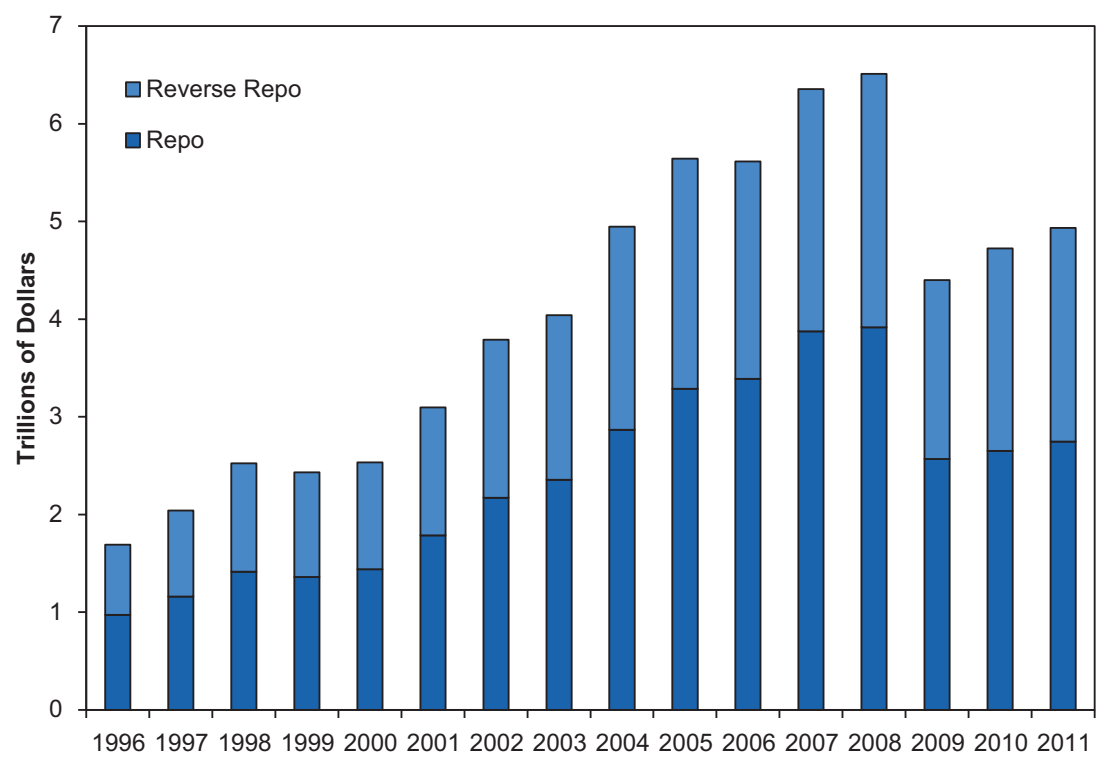

Source: Securities Industry and Financial Markets Association.

\subsection{Repo Market and the Crisis of 2007-09}

The financial crisis of 2007-09 was a crisis not only of the traditional banks but also of the shadow banks. ${ }^{16}$ Unlike traditional banks, shadow banks did not have access to the safety nets designed to prevent wholesale runs on banks - deposit insurance and the central bank as the lender of last resort - until 2008. Although there was no wholesale run on the traditional banking system in this period, we effectively observed a run on shadow banks that led to the demise of a significant part of the shadow banking system. Since repo financing was the basis of most of the leveraged positions of the shadow banks, a large part of the run occurred in the repo market. Other important

\footnotetext{
${ }^{16} \mathrm{~A}$ shadow bank is a non-bank financial institution that behaves like a bank, borrows short term in rollover debt markets, leverages itself significantly, and lends and invests in longer-term illiquid assets. Unlike banks, however, the shadow banks are much less regulated (Acharya and Öncü 2010).
} 


\section{Figure 3. Growth of Tri-Party Repo Market}

Trillions of dollars, monthly average

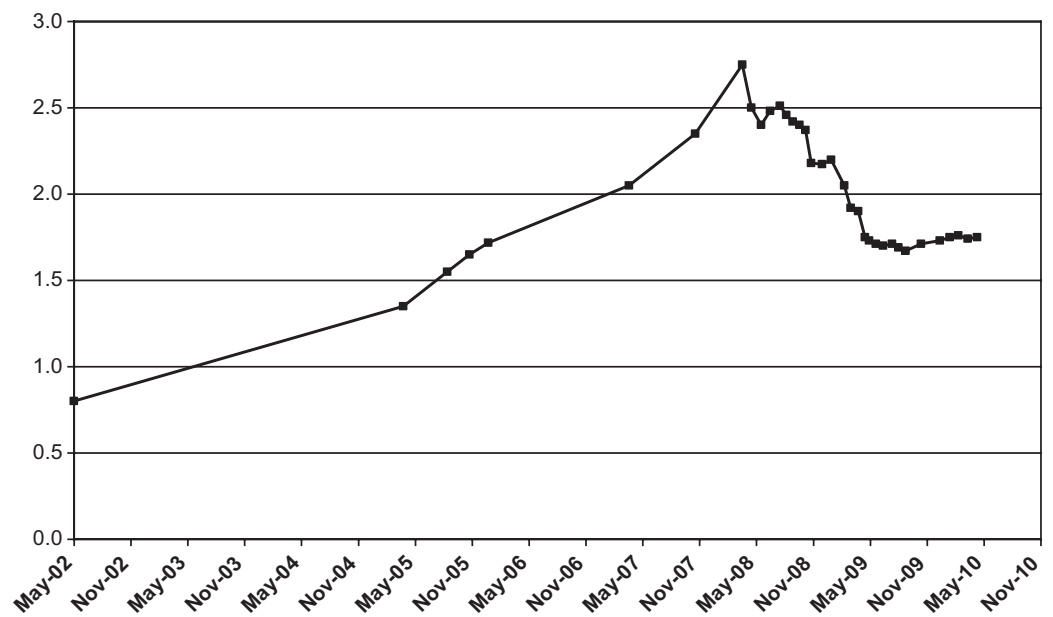

Source: Federal Reserve Bank of New York (2010).

runs that occurred in this period were on mortgage lenders, assetbacked commercial paper (ABCP) programs, structured investment vehicles (SIVs), and money-market funds.

When the housing market changed course in the first quarter of 2006, the subprime mortgage market began to deteriorate. The first casualty of the continued weakness in the housing market was in the form of the collapse of two highly levered Bear Stearns hedge funds that invested in subprime mortgages on June 20, 2007. The collapse of these two hedge funds was indeed a run on a shadow bank in the repo market. The two funds (one of which at its peak was levered ten times its equity) were speculating mostly in CDOs on subprime mortgages, borrowing funds in the repo market, and pledging their CDOs as collateral.

With the deterioration of the subprime market in the first half of 2007, creditors began asking the two Bear Stearns funds to post more collateral to back the repos by mid-June 2007. When the funds failed to meet these margin calls, creditors, led by Merrill Lynch, threatened to declare the funds in default of repo agreements and seize the investments. In fact, on June 19, 2007, Merrill seized \$850 million of the CDOs and tried to auction them. When Merrill was able to 
sell only about $\$ 100$ million worth of CDOs, the illiquid nature and the declining value of subprime assets became evident. Bloomberg reported that at least seven other lenders, including Lehman Brothers and Deutsche Bank, also circulated lists of CDOs and other bonds that they were planning to sell. This shadow bank run and the systemic crisis that followed illustrate the significance of the exemption of repo securities from the application of automatic stay; had the repo securities been subject to automatic stay (or alternatives proposed below), the Bear Stearns funds could have filed for bankruptcy and the forced fire sale of their assets could have been avoided.

Eventually, the subprime mortgage decline became systemic. In early August 2007, a run ensued on the assets of three SIVs of BNP Paribas. On August 9, BNP Paribas suspended redemptions from these SIVs. BNP Paribas's SIVs were bankruptcy-remote entities financing their subprime holdings through the issuance of ABCPs that had essentially lost their liquidity and became nontradable. The announcement of the suspension of redemptions by BNP Paribas gave rise to counterparty risk concerns and caused the ABCP market to freeze. This freeze coincided with the first major jump in the LIBOR-OIS spread. When fears of counterparty risk spread through markets, all short-term debt markets - including the repo market - froze, only to open after central banks injected massive amounts of liquidity into the system (see Acharya and Richardson 2009).

Based on a data set obtained from dealer banks, Gorton and Metrick (2009b) studied the repo spreads and haircuts for various types of repo securities. The spreads and the haircuts reported in their work are only for dealers; non-dealer counterparties may have been subject to other spreads and haircuts. The repo spreads are the spreads between the three-month repo and the three-month OIS rates. Their results demonstrate clearly how a crisis that started in the subprime market spread like a wildfire to other types of comparable nontransparent securitized debt, such as automobile, credit card, and student loan asset-backed securities, as well as the high-credit-rated structured products, such as AAA- and AA-rated CLOs and CDOs.

As Gorton and Metrick claim, the increasing haircuts in the interdealer repo market may be interpreted as a run on shadow banks. Figure 4, reproduced from Gorton and Metrick (2009a), shows how that run evolved. The data they examine are the interdealer 


\section{Figure 4. Repo Haircuts on Different Categories of Structured Products}

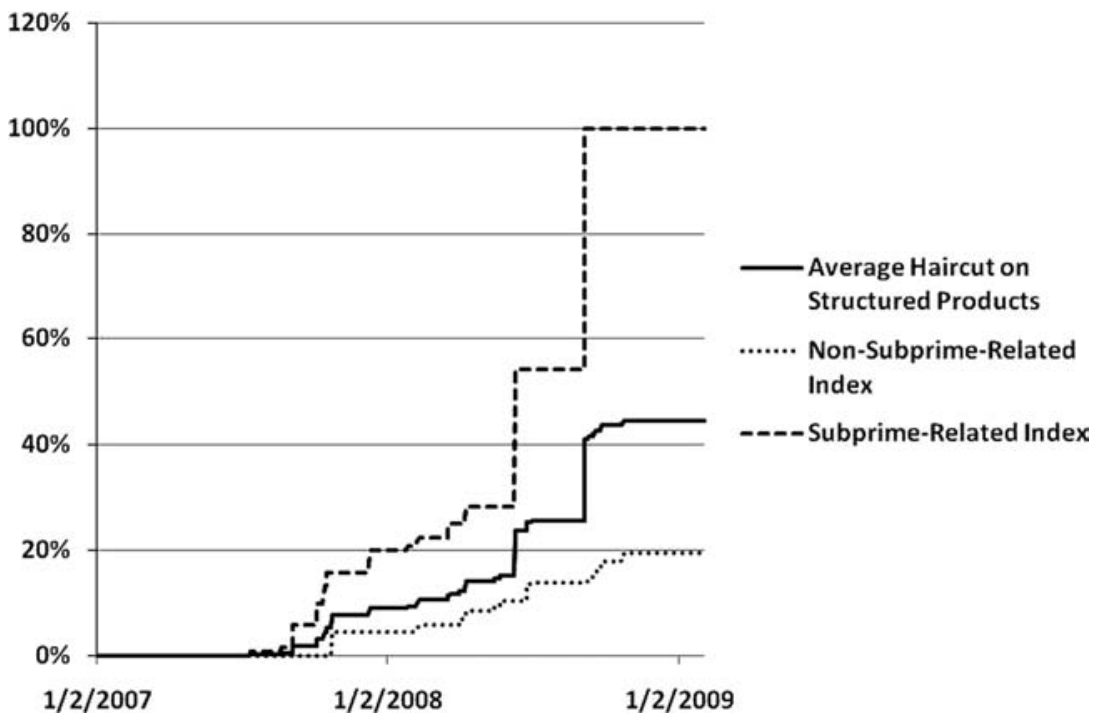

Source: Reproduced from Gorton and Metrick (2009a).

repo haircuts for the following asset classes: (i) A-AAA auto/credit card/student loan ABS; (ii) AA-AAA RMBS/CMBS; (iii) $<$ A RMBS/CMBS; (iv) AA-AAA CLOs; (v) unpriced ABS/MBS/all subprime; (vi) AA-AAA CDOs; and (vii) unpriced CLOs/CDOs (where "unpriced" means that the collateral does not have public pricing on either Reuters or Bloomberg). Of these, the categories (i)-(iv) do not contain subprime mortgages and are labeled "nonsubprime related" by Gorton and Metrick. In particular, the RMBS referred to in categories (ii) and (iii) are prime mortgages. The categories (v)-(vii) are either directly subprime or contain subprime mortgages. CDOs, in particular, contain some subprime mortgages. Finally, using all seven categories, they also construct an equalweighted average repo haircut index for structured bonds.

As can be seen from figure 4, the run on the shadow banking system in the interdealer repo market occurred in two phases. Although Bear Stearns's hedge funds were the first victims, it was BNP Paribas's suspension of redemptions on its three SIVs that triggered the first phase in August 2007. The failure of Bear Stearns 
in mid-March 2008 was the next phase of the run in the repo markets. It was not only the interdealer repo market for less-liquid collateral that Gorton and Metrick (2009b) studied where repo runs occurred. The FRBNY white paper (2010) states:

At several points during the financial crisis of 2007-09, the triparty repo market took on particular importance in relation to the failures and near-failures of Countrywide Securities, Bear Stearns, and Lehman Brothers. The potential for the tri-party repo market to cease functioning, with impacts to securities firms, money market mutual funds, major banks involved in payment and settlements globally, and even to the liquidity of the U.S. Treasury and Agency securities, has been cited by policy makers as a key concern behind aggressive interventions to contain the financial crisis.

Consider, for instance, the "run" on Bear Stearns. ${ }^{17}$ As an intrinsic part of its business, Bear Stearns relied day to day on its ability to obtain short-term financing through secured borrowing. At this time, Bear was reported to be financing $\$ 85$ billion of assets, primarily MBS, on the overnight market (Cohan 2009). Beginning late Monday, March 10, rumors spread about liquidity problems at Bear Stearns. Counterparties became unwilling to lend on customary terms. In particular, Federated and Fidelity - two money markets usually rolling over $\$ 5$ billion each of repo financing to Bear-did not roll over. This unwillingness to fund on a secured basis placed enormous stress on the liquidity of Bear Stearns. On Tuesday, March 11 , the holding company liquidity pool declined from $\$ 18.1$ billion to $\$ 11.5$ billion (see figure 5). On Thursday, March 13, Bear Stearns's liquidity pool fell sharply and continued to fall on Friday. In the end, the fear of repo financiers that they would be left with highly illiquid MBS collateral to sell in the market led to a "run" and the near failure of the firm, which was eventually sold with assistance of the Federal Reserve to JP Morgan. In contrast to the smoothly rising haircuts in the bilateral repo market shown in figure 4, financing

\footnotetext{
${ }^{17}$ The discussion that follows is based on the Securities and Exchange Commission press release on March 20, 2008, entitled "Chairman Cox Letter to the Basel Committee in Support of New Guidance on Liquidity Management," available at www.sec.gov/news/press/2008/2008-48.htm.
} 


\section{Figure 5. Bear Stearns' Liquidity Pool Just Before Its Near Failure}

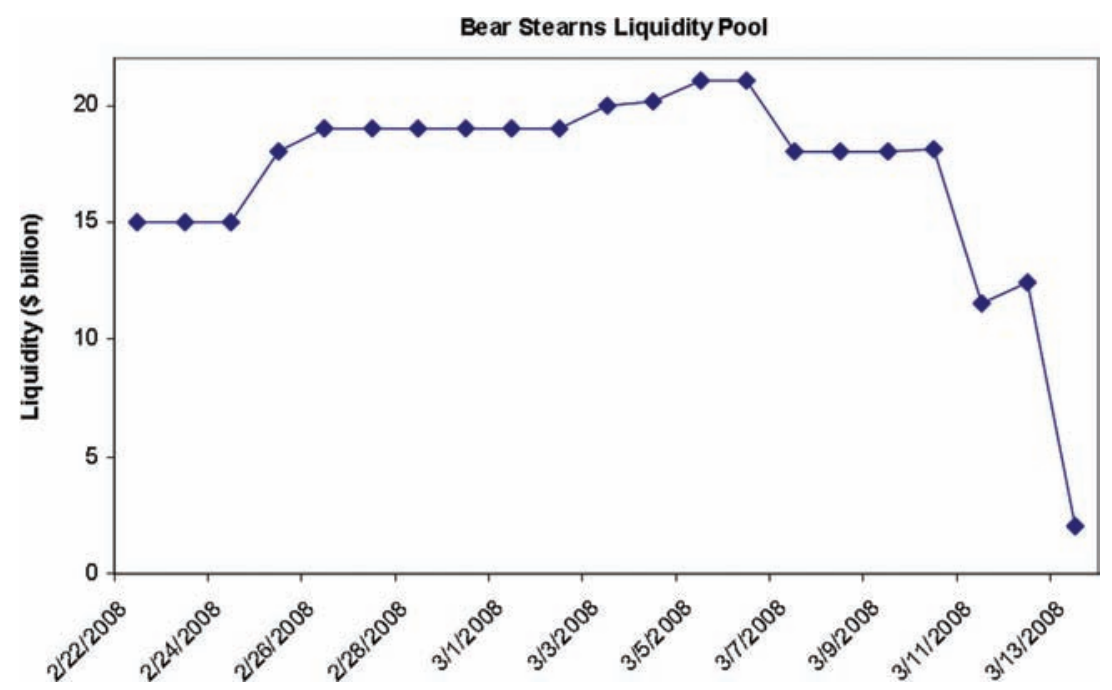

Source: SEC Chairman Christopher Cox's letter to Basel Committee in support of New Guidance on Liquidity Management. Available at www.sec.gov/news/ press/2008/2008-48.htm.

terms for Bear Stearns in the tri-party repo system did not rise dramatically, but it experienced a sudden freeze or a "run" from some of its largest repo financiers who feared acquiring the underlying collateral and fire-selling it in an illiquid market.

After Bear Stearns collapsed in March 2008, the Federal Reserve introduced its most radical change in monetary policy since the Great Depression by extending its lender-of-last-resort support to the systemically important primary dealers through the new Primary Dealer Credit Facility (PDCF). However, even this extension of the lender-of-last-resort facility did not prevent the run on Lehman Brothers, as investors realized that this support was not unconditional and unlimited (see Acharya, Schnabl, and Suarez 2009). ${ }^{18}$

\footnotetext{
${ }^{18}$ While the largest haircut jump in figure 4 corresponds to the collapse of Lehman on September 15, 2008, the second largest jump, which came in the summer of 2008, corresponds to traditional bank runs on likely insolvent banking institutions, such as IndyMac, Washington Mutual, and Wachovia.
} 
Indeed, using data collected by the Federal Reserve Bank of New York to document quantitative features of this market, Copeland, Martin, and Walker (2010) studied the tri-party repo market and demonstrated that haircuts in the tri-party repo market barely moved during the crisis. They found that both the level of haircuts and the amount of funding were surprisingly stable in this market during the period from July 2008 to early 2010 for which they had data. ${ }^{19}$ Although the stability of the margins was in contrast to evidence from other repo markets, they provided evidence that "this apparent stability did not prevent the tri-party repo market from contributing to the problems experienced by Lehman Brothers. . . . The available evidence suggests that runs in the tri-party repo market may occur precipitously, more like traditional bank runs, rather than manifest themselves in the form of large increases in margins." Figure 6, reproduced from Copeland, Martin, and Walker (2010), provides a feel for the run on Lehman in the tri-party repo market they documented (see Copeland, Martin, and Walker 2010 for details).

With the Lehman bankruptcy on September 15, 2008, the repo market on even U.S. government debt, federal agency debt, corporate debt, and federal agency mortgage-backed securities came to a near halt, and settlement fails of primary dealers skyrocketed. Table 1 shows a quarterly summary of the primary dealer settlement fails from the first quarter of 2007 to the last quarter of 2009 . Figure 7 provides a quarterly summary of the effects of the run on the repo market on the financing of primary dealers after Lehman's collapse. As shown, it was the borrowing ability of the primary dealers that went down significantly, not their lending ability. Since this may be interpreted as large withdrawals from the broker-dealer shadow banks in the repo market, figure 7 also illustrates the disappearing confidence in the shadow banking system and the severity of the run on shadow banks. When the Federal Reserve and the U.S. government let Lehman collapse, the next in line for a run, Merrill Lynch, had to merge with Bank of America. Shortly thereafter, the two

\footnotetext{
${ }^{19}$ This finding is also corroborated in Krishnamurthy, Nagel, and Orlov (2011), who also attribute the relative stability of the tri-party repo market to the substitute for repo funding provided by Fed-initiated liquidity facilities against illiquid collateral, especially following the collapse of Bear Stearns.
} 


\section{Figure 6. Lehman Brother's Tri-Party Repo Book by Collateral Type}

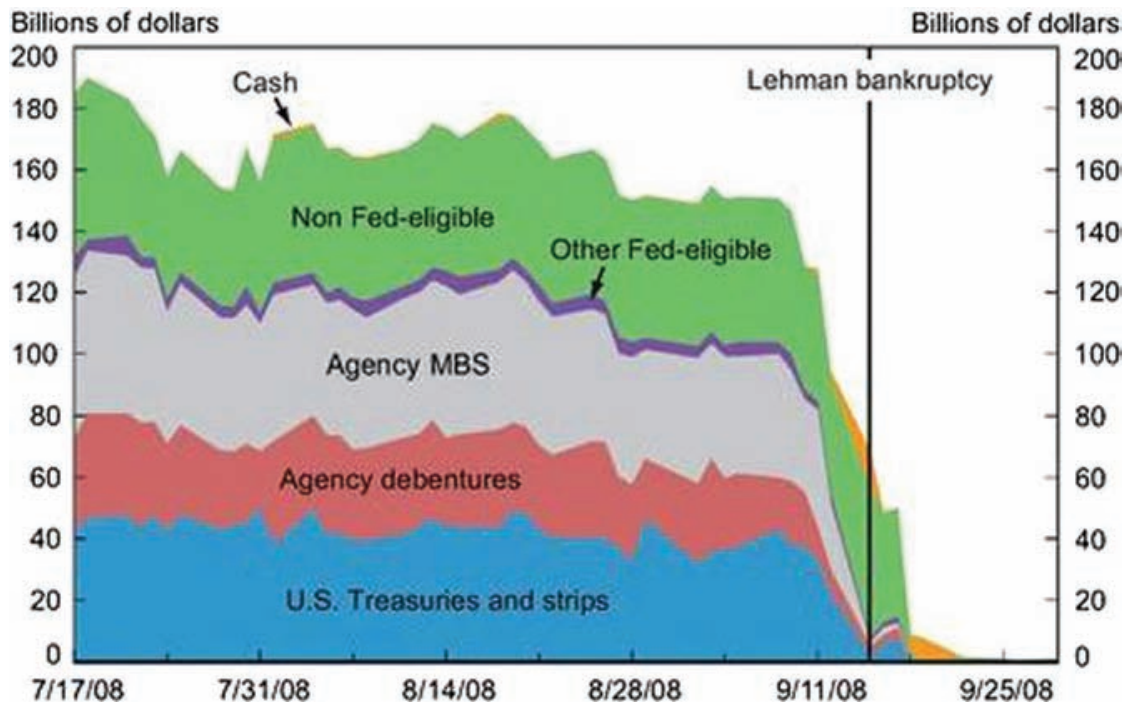

Source: Copeland, Martin, and Walker (2010).

remaining independent broker-dealers, Morgan Stanley and Goldman Sachs, were forced to convert to bank holding companies and were formally put under supervision and regulation of the Federal Reserve. In fact, the entire Wall Street system of independent brokerdealers collapsed in a matter of seven months (see Acharya, Schnabl, and Suarez 2009).

\subsection{A Case for Reforming the Repo Market}

As Acharya and Krishnamurthy (2010) clarify, the primary issue with financing risky securities (such as mortgage-backed securities) through repo markets is that such financing is likely to freeze or experience stress in times of aggregate (economy- or financial-sectorwide) stress, and on their own, financial firms do not have the incentive to internalize the costs of such a freeze or stress. By virtue of being secured and typically short-term financing arrangements, repo markets, by and large, function smoothly; in other words, repos usually get rolled over. When the underlying assets, such as Treasury 


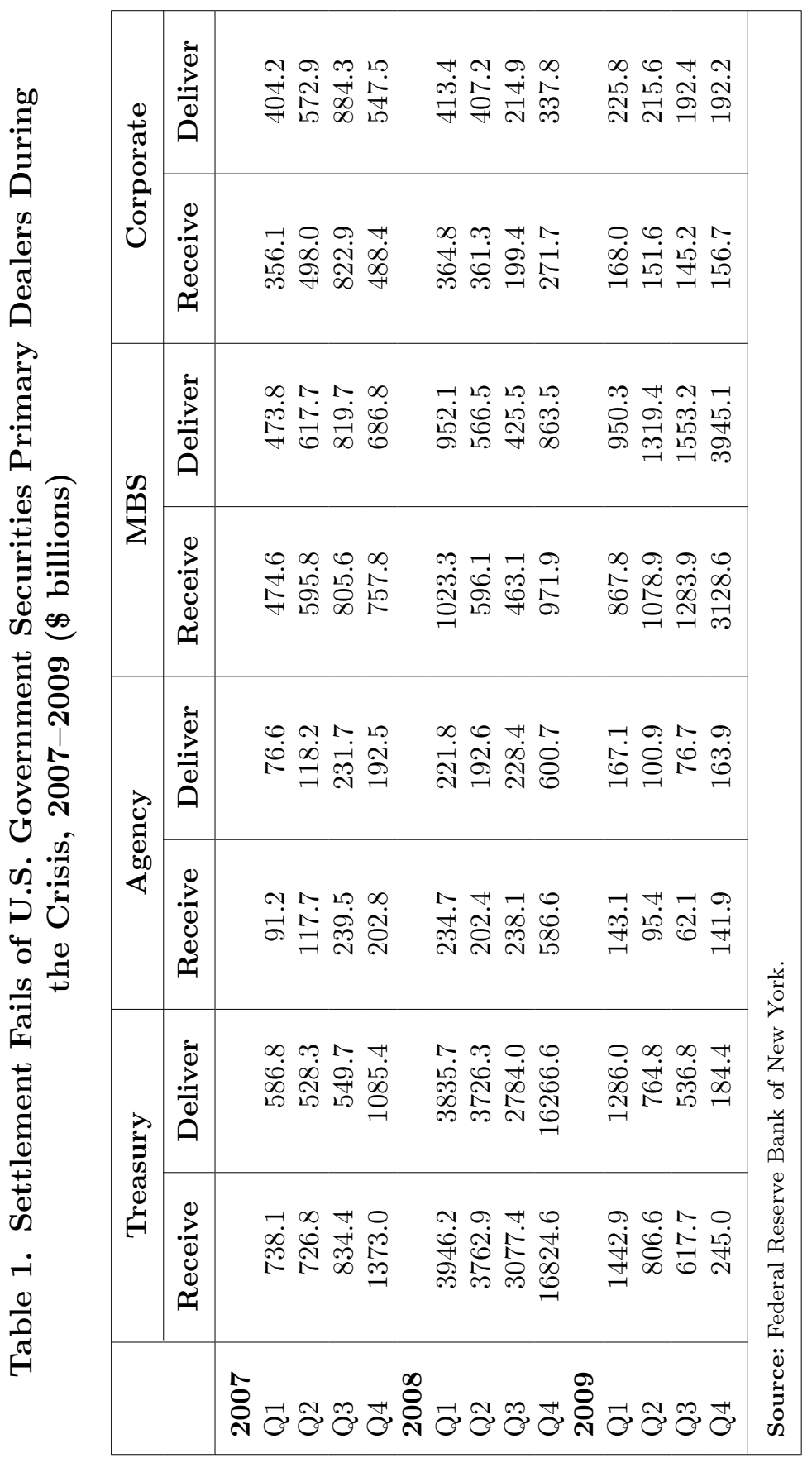


Figure 7. Quarterly Averages of Daily Financing by U.S. Government Securities Primary Dealers, 2006-11

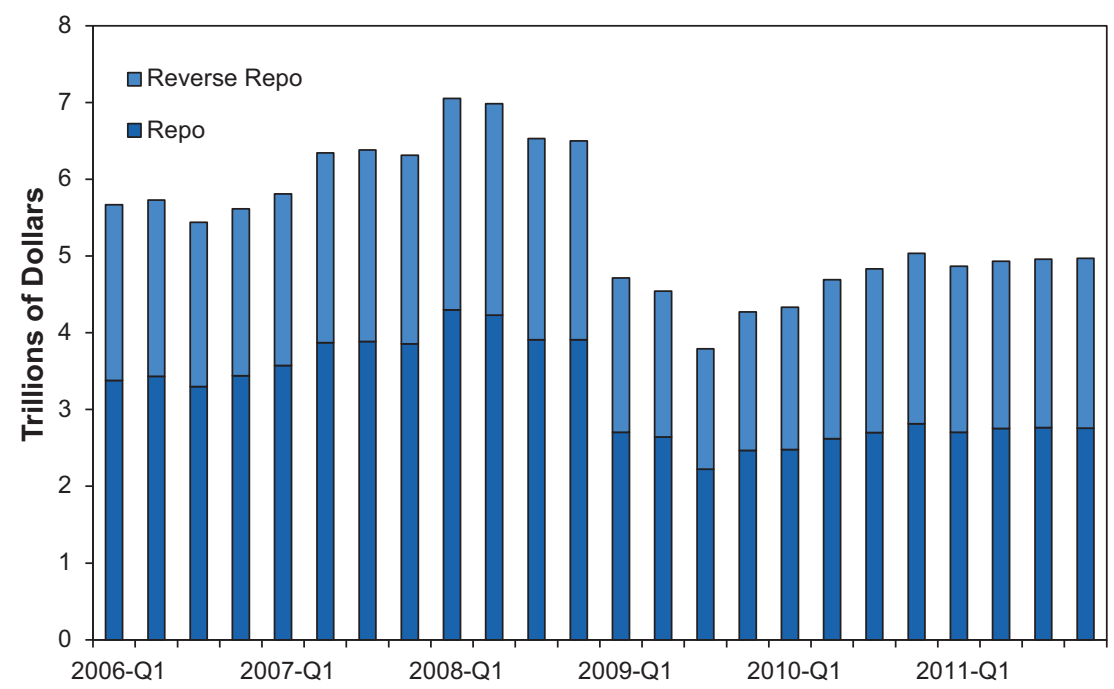

Source: Securities Industry and Financial Markets Association.

or agency debt, are essentially safe, the repo financier is undeterred from rolling over the financing even in stressful times. Indeed, Treasury and agency debt might even experience a flight to safety in such times.

In contrast, if the underlying collateral is a mortgage-backed security and an economic downturn ensues, the risk of an already illiquid market for MBS gets compounded; this is because many financial institutions' portfolios are crowded with MBS or have lost capital. In this scenario, repo financiers run the real risk of being forced to sell their collateral in illiquid markets. The repo financier may respond by raising the required haircut or simply refusing to roll over. The resulting fall in repo financing ability against the collateral is perverse, as it sets up an adverse dynamic: The future buyers of assets anticipate that they are likely to face steep haircuts too and thus will not offer attractive prices for assets; in turn, the collateral's ability to be financed with repo today falls even further. A complete market freeze can arise, as it did during the crisis 
of 2007-09. Indeed, in his analysis of the failure of Bear Stearns, Federal Reserve Chairman Ben Bernanke (2008) observed:

Until recently, short-term repos had always been regarded as virtually risk-free instruments and thus largely immune to the type of rollover or withdrawal risks associated with shortterm unsecured obligations. In March, rapidly unfolding events demonstrated that even repo markets could be severely disrupted when investors believe they might need to sell the underlying collateral in illiquid markets. Such forced asset sales can set up a particularly adverse dynamic, in which further substantial price declines fan investor concerns about counterparty credit risk, which then feed back in the form of intensifying funding pressures. . . . Future liquidity planning will have to take into account the possibility of a sudden loss of substantial amounts of secured financing.

To summarize, unlike the liquidity risk that unsecured financing may become unavailable to a firm (a risk largely specific to the credit risk of the firm), the liquidity risk that secured repo financing may become unavailable to a firm is inherently a systemic risk, materializing in circumstances where other financial firms are also experiencing stress and the markets for assets held predominantly by the financial sector are rendered illiquid. This leads to the problem that while in good times, financial firms may not fully internalize the costs imposed on the system by being excessively financed through short-term repo markets, in bad times, they charge excessively high haircuts on repo financing and do not internalize the pecuniary externalities imposed on other firms through the resulting fire sales of assets. Indeed, to support financial firms facing a repo freeze or to support the assets directly, the likely lender of last resort would only accentuate a problem that firms ignore in good timesnamely, the systemic risk associated with repo financing. Viewed this way, in good times, there is a case for subjecting repo-financed risky securities to a capital charge -effectively a regulatory haircutwhich takes into account the security's systemic risk and maturity mismatch relative to the repo tenor. Equally important, there is a case for a better design of the bankruptcy of a repo-financed debtor than simply granting its repo financier the full right to seize the collateral and liquidate it at will in an illiquid market. 


\section{Proposal for a Repo Resolution Authority}

Although the DFA is completely silent about how to reform the repo market, at least two attempts have been made to address weaknesses inherent in it. The first of these attempts was made by the Committee on Payment and Settlement Systems (CPSS) of the Basel Committee on Banking Supervision, which undertakes specific studies in the field of payment and settlement systems. The CPSS commissioned a working group on repo market infrastructure "to investigate the extent to which the clearing and settlement infrastructure for repos contributed to the instability evident in some repo markets" in June 2009. ${ }^{20}$ After a comprehensive survey of the clearing and settlement arrangements for repos in selected CPSS member countries, the working group published their report in September 2010. ${ }^{21}$ Their conclusion was that it was worthwhile for the stakeholders in each market to review how the clearing and settlement arrangements for repos could be further strengthened.

The second of these attempts was made by the Tri-Party Repo Infrastructure Reform Task Force (the Task Force) which was formed "to address weaknesses that became visible over the course of the recent financial crisis" in September 2009, under the auspices of the Payments Risk Committee, a private-sector body sponsored by the Federal Reserve Bank of New York. ${ }^{22}$ The Task Force published its final report with recommendations to strengthen the infrastructure supporting the tri-party repo market in May 2010. ${ }^{23}$ The July 6, 2011, progress report of the Task Force indicated that although progress had been made in regards to implementing the reforms recommended in May 2010, they were behind the schedule and continuing to develop the remaining steps to achieve their objectives. ${ }^{24}$ The focus of the Task Force had primarily been on the issue of whether JP Morgan Chase and the Bank of New York, the tri-party brokers, extend credit risk intraday, how that risk could be mitigated or adequately capitalized, and other intraday infrastructure

\footnotetext{
${ }^{20}$ See www.bis.org/cpss/index.htm.

${ }^{21}$ See www.bis.org/publ/cpss91.htm.

${ }^{22}$ See www.newyorkfed.org/tripartyrepo/.

${ }^{23}$ See FRBNY (2010).

${ }^{24}$ See www.newyorkfed.org/tripartyrepo/pdf/PR_110706.pdf.
} 
issues. The Task Force released its final report on February 15, 2012 and reported that despite significant accomplishments, their ultimate goal of the "practical elimination" of intraday credit extension by the clearing banks was years away. Consequently, the Federal Reserve decided to explore additional policy options, including limitations on eligible collateral and a "facility to foster the orderly liquidation of collateral in the event of a dealer's default" (see Tuckman 2012a for details). ${ }^{25}$

On balance, the macroprudential issue of containing bank-style runs in the repo markets and the risk of fire-sale liquidations of illiquid collateral such as mortgage-backed securities has not been discussed substantially. On this macroprudential issue, possible reforms of the repo market can be put into three categories:

(i) a full government-guarantee scheme for repo market liabilities;

(ii) a full market-discipline scheme in which repo liabilities are not exempt from bankruptcy but are subject to automatic stay, as with secured borrowing contracts of non-financial firms; and

(iii) a combination of the two. As we explain below, our preferred alternative is the combination but where guarantee extended is in the form of a temporary liquidity guarantee and its potential moral hazard consequences are controlled for.

At one extreme, some (most notably, Gorton 2009) have suggested that repo financing is akin to demandable deposits in many ways and thus is similarly vulnerable to the information-sensitive panics when adverse information about underlying collateral (or counterparties) hits markets. His proposal is thus to treat repo financing in a similar way - that is, offer federal deposit insurance to the repo contracts, at least against securities that are relatively "safe," such as the super-senior tranches of securitization pools and "deposits" (technically savings) with the money-market funds. Under this proposal, it is recognized that repo financing has the inherent systemic fragility akin to demandable deposits, and in all

\footnotetext{
${ }^{25}$ Interestingly, "limitations on eligible collateral and a facility to foster the orderly liquidation of collateral" were among the policy suggestions we also had made in an earlier work (see, Archarya and Öncü 2010).
} 
likelihood, the government would end up backing up repo counterparties were the fragility to materialize. Hence, by explicitly recognizing the guarantee up front, it becomes possible to charge repo financiers for the guarantee. As with any insurance premium, the objective is not only to collect fees for an ex post guarantee but also to get repo financiers to internalize the systemic fragility inherent in repo contracts.

At another extreme, others (most notably, Roe 2009 and Perotti 2010) have proposed that repo financiers should not be allowed unrestricted access to collateral even in the case of default of the counterparty. That is, there should be some sort of "automatic stay" on repo financiers' claims, and they should join the bankruptcy of the defaulting counterparty as a secured creditor, as in the case of corporate bankruptcies. The rationale for this is twofold: first, it prevents the systemic liquidity risk due to fire sales of the repo collateral by the financiers and avoids the adverse dynamic we highlighted before; and second, by exposing the repo financiers to credit risk of the counterparty (and not just that of the collateral), the financiers would subject the borrowers to much greater market discipline. In particular, financiers would opt for safer counterparties, all else being equal, or charge higher haircuts to riskier ones - either way, discriminating ex ante between safer and riskier borrowers.

The advantage of the government guarantee scheme is that it resolves virtually all ex post uncertainty by transferring the risk of repo contracts away from financiers to the government agency for an upfront fee. However, its disadvantages are more subtle and somewhat pernicious. The charging of FDIC premiums has been heavily influenced by the banking industry, and no premiums have historically been charged to most banks when the FDIC's reserve fund is capitalized above 1.25 percent to 1.35 percent of the insured deposits. This kind of a fee structure gives rise to a highly procyclical risk-taking incentive, because, as far as the risk-return trade-off is concerned, the risks are backloaded. There is no guarantee that repo insurance premiums would work any differently. Perhaps, and somewhat more disturbingly, such a guarantee scheme effectively amounts to transferring the credit risk of virtually most parts of the securitization market to the government's balance sheet. While "conforming" mortgages in the United States are already being backstopped by Fannie Mae and Freddie Mac, the proposed guarantee 
scheme would extend such a backstop to subprime securitized pools, corporate loans, automobile receivables, credit card receivables, and so on. Due to its potential sovereign risk concerns in an environment of difficult fiscal position for the government, the idea of extending guarantees to practically all financial assets of the economy should be viewed with caution. Such caution would be even more necessary for governments other than the United States whose balance sheets are already heavily stretched.

On the other hand, the advantage of market discipline through the automatic stay approach is that it transfers the entire risk of the repo transaction to the repo financier-to some extent the risk of the collateral but also that of the borrower's ability to pay. This way, other than through ex post forbearance, private markets are allowed to function - bear and price risks - and thereby provide incentives to take into account relevant risk-return trade-offs. There are, however, several countervailing issues that arise. First, since the primary issue with repo contracts is their systemic externality, it is unclear that private market outcomes would be necessarily efficient from a risk-return standpoint of the economy as a whole. Second, automatic stay introduces "basis risk" in the repo contract, since its eventual payoff is linked not just to the underlying asset but to the whole pool of assets of the borrower and the rest of its capital structure. In general, this may create sufficient ex ante, as well as ex post, uncertainty to reduce the financier's willingness to lend against certain assets to all types of borrowers. The result might be a significant reduction in ex ante liquidity in some parts of repo-financed securitized markets. Third, a rationale for the bankruptcy exemption of the repos has been that when the borrower defaults, counterparty risk transmission is reduced as far as the repo contract goes because it is protected from any spillover of the borrower's remaining risks and liabilities.

Given this relative assessment, our preferred approach is one that facilitates a ready winding down of the repo contracts as far as reasonable liquidity for repo financiers is concerned and at the same time eliminates disorderly fire sales of underlying assets. In particular, the approach consists of setting up a repo resolution authority that meets the criteria (i)-(v) we laid out in the Introduction for resolution of SIALs. In case of default of a repo counterparty (the borrower), the repo resolution authority would ensure orderly 
resolution of its repo liabilities and also an orderly liquidation of the underlying collateral; in good times, the repo resolution authority would ensure that the services it provides at time of default are not contributing to excessive risk of defaults in the repo markets.

Specifically, instituting the repo resolution authority requires the following pieces:

(i) In case of default of a borrower, its repo counterparties on Treasuries, and perhaps agency-backed securities (assuming the agency-backed securities are effectively government backed), are "exempt from stay" and counterparties are allowed to take their collateral as under the current arrangements.

(ii) However, repo counterparties on risky collateral, such as ABS and MBS, are subjected to a "stay" (or a suspension of conversion to immediacy) as with secured borrowing of non-financial firms.

(iii) Immediately upon default, repo financiers of risky collateral are paid by a "repo resolution fund" a recovery amount that is based on a conservative value assessment of the collateral. ${ }^{26}$ Such a value assessment could be based on market intelligence, historical estimates, projected valuations obtained from a poll of dealers, etc. The important issue is that the assessment should be "conservative" and reflect reasonable haircuts that an asset liquidator would expect to incur when faced with asset liquidations. In particular, the conservative value could be dependent on the total size of repo liabilities of a borrower and/or on the total size of liabilities against a given type of collateral. The conservative recovery amount (or its schedule) should, however, be predetermined and known to market participants.

(iv) In case of default on repo backed by risky collateral, the underlying repo collateral is taken over by the repo resolution

\footnotetext{
${ }^{26}$ The repo resolution fund could be dedicated to the repo resolution authority, or it is conceivable that it could simply be within the FDIC or the Federal Reserve. The fund should potentially be eligible for participating in the lender-oflast-resort facilities of the central bank. If such participation is not clear a priori, uncertainty concerning it could lead to the breakdown of our proposed resolution plan.
} 
authority (which effectively has liquidation rights over the collateral) and liquidated in an orderly manner over a prespecified period - say, not more than six months (but with some flexibility to deal with unexpected circumstances).

(a) If the eventual recovery on the collateral is greater than the conservative estimate paid to the repo financiers (see step (iii) above), then the time-value adjusted difference is paid eventually to the repo financiers.

(b) Conversely, if the eventual recovery is lower than the conservative estimate paid to the repo financiers, the timevalue adjusted difference is "clawed back" from the repo financiers. The clawback feature would have to be explicitly legislated (as with the current mechanism used by FDIC to deal with uninsured depositors of failed FDICregulated banks).

(v) In effect, steps (iii) and (iv) resemble a lender-of-last-resort (LOLR) operation, whereby risky collateral in times of a systemic crisis would be provided liquidity, albeit conservatively at a "haircut" or penalty rate. The operation is of the LOLR flavor since it suspends immediate conversion to currency for repo financiers in the form of collateral liquidations and replaces it with an upfront but conservative payment by the repo resolution fund at time of default, with rights to liquidation conferred upon the repo resolution authority and not on repo financiers.

(vi) In the case of an isolated default in the repo market - that is, default in a time when the underlying collateral market is reasonably liquid - the collateral liquidation by the repo resolution authority would be relatively swift, at close to fundamental or liquid collateral values, and effectively the repo financiers will be repaid a conservative amount plus the additional recovery within a few days. That is, in this case, an effective automatic stay on repo contracts would be just a couple of days.

(vii) However, in the case of clustered defaults of several counterparties in the repo market - e.g., because there is an aggregate shock such as a significant housing-price decline or because the market for housing-related assets is weak due to overhang of other financial firms from holdings of similar assets - the 
collateral liquidation by the repo resolution authority could take time, and might not generate liquidation proceeds that are up to the conservative recovery payment made to repo financiers. This implies that

(a) the effective automatic stay on repo contracts would be more substantive, but in economic terms not as substantive as the asset liquidation period due to the conservative early payment made by the repo resolution fund, and

(b) importantly, the clawback feature would come into play and repo financiers could be required in part to return the liquidity provided by the repo resolution fund (when the time-adjusted eventual recovery is lower than the conservative recovery payment made at the time of default).

(viii) The clawback possibility in (vii)(b) above implies that the repo resolution authority takes on the credit risk of repo financiers, as well as of the underlying collateral. This credit risk is limited to the difference between realized recovery and the conservative estimate at the time of the borrower's bankruptcy, and is linked to the credit quality of the repo financier. In particular, if the repo financier defaults in the period when the repo resolution authority is liquidating the underlying collateral, then the repo resolution authority effectively becomes a creditor of the repo financier and may face losses if the repo financier defaults. To manage this credit risk, the repo resolution authority should

(a) include as eligible only relatively high-quality collateralthat is, certain highly risky securities such as pools backed by low-quality mortgages may be excluded from repo resolution authority altogether and repos with them as underlying collateral may be subject to the usual automatic stay, as in the case of secured borrowing by non-financial firms;

(b) charge repo financiers an ex ante fee for the lender-of-lastresort or conservative liquidity payment facility, commensurate with the residual credit risk borne by the facility, in order to provide a financing for the repo resolution fund;

(c) require that eligible repo financiers for the lender-of-lastresort facility provided by the repo resolution authority meet prespecified solvency criteria (which should be 
based on a range of solvency metrics, including market capitalization and funding capacity, rather than just easily arbitraged and static risk-weight style rules on book value of equity); and

(d) impose a concentration limit at the level of individual repo financiers, as well as on the financier's overall portfolio size, recognizing that controls in (a)-(c) above may mitigate credit risk borne by the repo resolution authority but not eliminate it altogether.

A difficult design issue in proposing such a resolution authority is to define the event of "default" of a repo borrower. One possibility is that given the ability of the authority to suspend conversion of immediacy of financiers, the borrower itself would have incentives to file for bankruptcy early, an option that currently would not give them the rights to stem runs from creditors who have safe-harbor provisions. Another possibility is that recognizing the incentives of distressed firms to gamble for resurrection and to avoid filing for bankruptcy, the resolution authority could itself define adequate default triggers that would suspend conversion of repo contracts on specific collateral and take over the asset liquidation rights (as outlined above). As we explained above, in the case of idiosyncratic distress of firms, the repo resolution authority would operate effectively like a safe-harbor provision, making the full payment upon swift liquidation of collateral to other firms. However, in the case of systemic distress, the repo resolution authority's ability to make partial immediate payments and liquidate collateral in due course would be most important. This suggests that the default trigger designed by the resolution authority would need to feature both firm-specific solvency and liquidity conditions as well as systemwide solvency and liquidity conditions. ${ }^{27}$

Thus, our preferred approach in the form of a repo resolution authority provides ex post liquidity to the repo market rather than a complete guarantee of underlying risks. This approach also charges

\footnotetext{
${ }^{27}$ The issue of whether the triggers should be based on book values of solvency and liquidity conditions or market values is an important and interesting one, raising the familiar trade-offs of the lagged and discretionary nature of book values against the timely but vulnerable (to manipulation and downward spiral) nature of market values.
} 
ex ante for this liquidity facility and ensures that the risks undertaken by the market participants do not expose the taxpayers to losses beyond a certain size. That is, it makes an effort not to take on solvency risk while trying to address liquidity risk of repo markets. It combines the attractive features of full insurance and full market-discipline schemes, avoiding their weaknesses. Furthermore, in contrast to FDIC's recent proposal of a fixed haircut for all repo collateral, it allows the haircut to be determined differentially for different collateral classes and sub-classes based on conservative value assessments at the time of the borrower's bankruptcy. As highlighted in the Introduction, it attempts to address the systemic risks of both the repo runs and the market for underlying collateral, while containing the ex ante risks created in the first place, and in a manner that can be harmonized internationally in a ready manner provided the various criteria in the scheme (i)-(viii) above are agreed upon by large repo centers of the world, or at least that they all meet some minimum reasonable standards.

Our proposal has similarities to the approach to regulation shadow banking laid out in Gorton and Metrick (2010). Specifically, the idea of limiting access to the safe-harbor or bankruptcy exemption clauses for specific types of collateral-backed repos is also a part of the Gorton-Metrick approach. However, there are also differences. The Gorton-Metrick approach recommends a government guarantee scheme, akin to deposit insurance, for liabilities of money-market funds, whereas under our approach, once moneymarket funds are subject to strict guidelines in repo market financing (and similarly in other SIALs), they would effectively be subject to solvency criteria similar to those for banks (and might not survive competition from banks in the first place). Further, while the primary risk control in the Gorton-Metrick scheme is through restriction of eligible collateral for safe-harbor provisions, safe harbor is in principle eliminated from our repo resolution authority and it just conditionally happens to be akin to safe harbor in some cases even for eligible collateral (when defaults are isolated as in (vi) above).

Our proposal also has some similarities to the Federal Liquidity Options proposal of Tuckman (2012b), which recommends that central banks pre-sell liquidity options as the exclusive means of lending money to non-banking institutions in a crisis. The idea of reducing 
the risk of the lender of last resort through paid-for commitments, and thereby minimizing the ex post socialization of residual risks, is in a similar spirit as our proposal. The difference is that our approach also proposes a mechanism to manage the residual risks not backed by the lender of last resort (or the repo resolution authority) once the ex ante commitments have been met (payments beyond conservative haircuts are made with immediacy).

Finally, Bliss and Kaufman (2011) propose refinements of the OLA under the Dodd-Frank Act that would apply regular bankruptcy proceedings to failing financial firms but with advance payments to such firms upon failure ("modified debtor-in-possession (DIP) financing") and mandatory but limited haircuts to all "protected" (e.g., safe-harbored) creditors. Both of these refinements also feature in our proposal, as immediate liquidity provided by the repo resolution authority to claims in failure and the credit risk on underlying collateral being passed on to the claims in due course. The key distinguishing feature of our proposal is that it grants the rights to large-scale asset liquidations to the resolution authority in order to address the issue of disorderly bankruptcy or fire sales when the failure of an institution is not in isolation but is coincident with other regulations.

It is important to discuss what would happen to repo contracts on collateral that is not eligible under the repo resolution authority and its strict guidelines and requirements. This would constitute the hypothetical "shadow banking" in a world of repo resolution authorities. These repo contracts would not have access to safe harbor and would be perceived as ex ante riskier and of lower liquidity by financiers. However, this would not necessarily guarantee that financiers internalize the externalities of runs in the shadow banking system. To guard against this, the repo resolution authority should, on a periodic basis, assess if a class of repo claims has become large enough and the underlying collateral is suitable quality enough to be eligible for repo resolution authority's LOLR. If yes, they should be required by legislation to be moved out of shadow banking into the repo resolution authority. And, where the underlying collateral is not of adequate quality or the repo contract class is not sufficiently small in size, a minimum haircut (or overcollateralization) requirement should be imposed, akin to FDIC's proposed haircut on all repos or a more risk-sensitive scheme such as bank capital 
requirements. Ideally, the haircut scheme should be countercyclical and certainly not procyclical (that is, not provide too-low or nonexistent haircuts in good times, such as on MBS with low-quality mortgages or government bond repos where government credit risk is non-trivial, as in the euro zone since 2008).

Having highlighted the various benefits of our proposed approach, such as its flexibility in extending to new asset and liability classes over time and the difficulty of gaming it by the financial sector since it operates for all institutions participating in a given asset or liability class, we note that it does - like the Dodd-Frank Act and the OLA - rely on a certain amount of ability of the regulators to get things right. In particular, the approach relies on regulators to be able to estimate conservative values of collateral which necessitates (perhaps incentivizes) them to ensure sufficient transparency of prices in underlying asset markets in normal times. The approach also relies on adequate incentives for the resolution authority to adopt ex ante risk controls in the form of haircuts, concentration limits, and eligibility restrictions on collateral, among others. While the approach can be harmonized internationally in a relatively straightforward manner, if such controls are harmonized, competition for market shares across borders can potentially put downward pressure on the adoption and the extent of these controls in practice. For this reason, besides the fact that the lenders of last resort such as central banks would ultimately have to step in when these authorities do not have adequate liquidity to make conservative payments, the lenders of last resort would need to act as watchdogs over our proposed resolution authorities, preventing a race to the bottom in their risk controls.

\section{A Historical Precedent: The Glass Proposal}

As Reinhart and Rogoff (2009) and Graeber (2011) documented, banking crises have been ubiquitous throughout recent history, and one problem common to almost all has been the loss of liquidity to bank depositors. In the wake of one of these crises - namely, the banking panic of 1907-the National Monetary Commission of the United States - established by Congress in the Aldrich-Vreeland Act 
of 1908 - prepared a nineteen-question questionnaire and mailed it to various representatives of the U.S. banking industry (Kaufman 2004). One of the questions - the eighteenth - asked: ${ }^{28}$

Would it be well, in your opinion, to change the existing laws so that liquidating banks could, in some way, arrange to pay depositors more rapidly? A careful examination of the assets of failed banks will show about how much dividend they can eventually pay, and considerable distress would be prevented if something approximating this amount could be paid to depositors without any delay.

As Kaufman (2004) reports, "Responses were obtained from 85 respondents. Of these, 63 , or some two-thirds, favored a change to pay depositors of closed banks more rapidly. This percent was the same among bankers and bank examiners, the two largest groups of respondents. Only 12 respondents, or $14 \%$ were opposed to such a change and the remainder either skipped the question or were undecided."

As we mentioned in the opening of section 2, a central objective of the DFA is to create a new resolution mechanism for non-bank SIFIs and bring them within the FDIC insurance model. In the wake of the next banking crisis after the panic of 1907, namely, in the early years of the Great Depression of 1929 and before the establishment of the FDIC in 1933, Senator Carter Glass - then chairman of the Senate Banking Committee and a coauthor of the Federal Reserve Act of 1933-proposed more-rapid payment to depositors at failed banks as a superior alternative to deposit insurance, which he opposed (Kaufman 2004). As quoted by Kaufman (2004), Willis and Chapman (1934, pp. 65-67) describe the objective of the Glass proposal as follows:

Recognizing that in bank failures the source of difficulty and loss is not primarily found in lack of assets, but ... that the resources of depositors are tied up and rendered unavailable for long periods ... liquidation power and not guaranty was demanded ... insuring an almost immediate settlement within a short time upon the basis of the estimated worth of the [failed] bank's

\footnotetext{
${ }^{28}$ As quoted by Kaufman (2004, p. 243).
} 
assets. . . . This plan was considered by the [Banking] Committee entirely adequate to the protection of the bank depositor against most of the evils to which he had been subject, while leaving him still with a measure of individual responsibility for the protection of his claims through the selection of a well-qualified bank.

The Glass proposal called for the establishment of a Federal Government Liquidating Corporation (FGLC) to estimate a bank's recovery value immediately upon its failure, quickly sell the bank as a whole or in parts, and quickly pay the proceeds to the receiver for speedy disbursement to the depositors (Kaufman 2004). Despite the differences, the similarities between our repo resolution proposal and the proposal of Senator Glass are astounding. Although we do not promote quickly selling the "repo banks" as a whole or in parts - except their highly liquid repo collaterals such as Treasuries, and perhaps agency-backed securities - for reasons we have argued at length, we also call for a liquidating agency (our repo resolution authority) to "estimate a (repo) bank's recovery value immediately upon its failure ... and quickly pay ... the receiver for speedy disbursement to the depositors (repo financiers)." In the first regard, our repo resolution authority resembles the Orderly Liquidation Authority of the Dodd-Frank Act more than the Federal Government Liquidating Corporation that Senator Glass proposed, since we are concerned also with the orderly liquidation of potentially illiquid and risky repo collaterals such as the MBS. In the second regard, our repo resolution authority resembles the FGLC of the Glass proposal more than the OLA of the DoddFrank Act because of our call for paying the repo financiers of risky repo collaterals a recovery amount that is based on a conservative value assessment of the collateral by a "repo resolution fund."

In the end, the Glass proposal was found too difficult to implement, primarily because many believed that it required moreaccurate estimates of the market value of the failed bank's assets than possible at the time (Kaufman 2004). This is another similarity between our proposal and the Glass proposal. Many may argue that our proposal requires more-accurate estimates of the market value of the risky and illiquid repo collaterals than possible at our 
time. Yet, the advantages of the scheme proposed by Senator Glass had also been seen by others.

For example, although it did not become operational, the Federal Reserve Bank of New York attempted to have depositors at failed banks receive the recovery value of their claims faster by requesting healthy member banks to buy the assets of failed banks and advance the proceeds to them for immediate distribution in 1931 (again, see Kaufman 2004 and the references therein). And, in 1933, the New York State Banking Department was able to implement such an arrangement when it entered into agreements with Manufacturers Trust Co. and other large New York City commercial banks to serve as both liquidating and paying agents for a failed bank and partially assume the deposits of the bank up to an agreed percentage of par amount (Upham and Lamke, 1934). As quoted by Kaufman (2004), Charles Clough, comptroller of Manufacturers Trust, noted the advantages of this program as follows:

Three things were definitely accomplished. Business men, whose working capital was frozen, were given relief through the release of their bank balances, and at the same time, were given immediate substantial banking connections which would enable them to continue in business; apparent distress among depositors was relieved at once; and the entire process of liquidation was accomplished more expeditiously and economically than was thought possible.

Another example, which is also an important precedent that relates to our proposal for a repo resolution authority and was inspired by the Glass proposal, is the Reconstruction Finance Corporation (RFC). The RFC was established by the Reconstruction Finance Corporation Act in 1932 and authorized to loan funds to banks closed for liquidation or reorganization to enable them to make quick partial payments to depositors. As Kaufman (2004) quotes from Jesse Jones, long-time chairman of the RFC, these loanssecuritized by the failed banks' assets - would

... make at least a part of the depositor's balance available to him, pending liquidation. . . . We endeavored to lend up to the probable liquidation value of their [the bank's] assets. ... The government could afford to wait; often the individual could not. 
The reason for the establishment of the RFC was that "freezing deposits at these banks was viewed as decreasing purchasing power in the community and delaying recovery from the Depression" (Kaufman 2004). Indeed, to avoid decreased purchasing power in the community and delayed recovery from the Depression, President Franklin Roosevelt suggested a deposit liquidation program "to stimulate and encourage liquidating agents of banks closed after January 1, 1933 to borrow funds from the RFC in order that funds may be made available to depositors as quickly as possible" (Upham and Lamke 1934, pp. 168-69).

However, the RFC did not agree to operate in the suggested program directly. For this and other reasons, Roosevelt established a new liquidation board, i.e., the Deposit Liquidation Board (DLB) to lend to the failed banks. The DLB could borrow from the RFC using the assets of the failed banks as collateral, but it charged the banks a lower interest rate on the loans than the rate charged by the RFC (Kaufman 2004). The DLB loaned on 80 percent of the liquidation value of the assets, but this liquidation value was determined not on the basis of the current book value of the failed bank's assets but on values that the RFC projected it could get in "an orderly liquidation period of three to five years in a recovering stock and bond market" (Olson 1988, p. 75).

Although the volume of loans provided by the DLB increased rapidly in 1933, it was still considered by some as too little and too slow. A number of bills were introduced in Congress to have the Treasury or other federal agencies also advance funds to depositors at closed banks, but, despite gathering considerable support, none of the bills were enacted (Calomiris and White 1994). Kaufman (2004) notes that "authority to provide such loans was, however, included in the Federal Deposit Insurance Act, although apparently not used to liquefy frozen uninsured deposits until 50 years later in 1983. With the sharp decline in the number of bank failures after 1934, legislative interest in liquefying deposits at failed banks diminished."

\section{Concluding Remarks}

Regulators and policymakers in the United States and abroad have made rough sketches of proposals that would avoid bankruptcy 
proceedings for systemically important financial institutions (SIFIs). One idea is that there should be provision of "contingent capital" or "co-co bonds," a (small) part of SIFI's liabilities that would convert to equity mechanically based on a firm-specific and/or systemspecific trigger. Such conversion would provide the SIFI with some debt relief and thus some extra time to deal with its problems. A related idea is that of a "bail-in" under which a SIFI's deterioration past a specified benchmark would trigger for some claims a pre-specified haircut or the elimination of some claims entirely, effectively writing down firm's liabilities to a predetermined extent. Bail-ins in particular are attractive if they can be enacted as part of an integrated capital structure, wherein SILs (such as swap agreements) are placed in high-priority tranches while ordinary bonds and equity are left to suffer conversion or elimination in the event that the firm would be unable to pay all of its obligations. Such a capital structure, enacted perhaps as part of a SIFI's living will - a plan of resolution required for the U.S. firms by the DFA - could lend stability by providing certainty about where losses would rest in the event of a financial crisis.

What we propose, based on the insights of Acharya, Adler, and Richardson (2011), is that "top-down" (or institution-level) approaches such as contingent capital, bail-in, or living wills be built on top of a "bottom-up" approach-one that works at the level of the SIALs rather than at the level of the SIFI that owns them. Under the bottom-up approach there would be an automatic stabilizer built into each systemically significant part of an SIFI's capital structure. The automatic stabilizers could be in the form of government-provided but appropriately charged deposit insurance, centrally cleared SIALs with initial and variation margins or haircuts charged by a clearinghouse or dedicated resolution authority for those SIALs, and, in extreme cases, lender of last resort from the central bank against eligible assets (but to avoid moral hazard, only to firms that pay a market-rate fee). A particularly attractive feature of this "bottom-up" approach is that it requires no uniform institution-level insolvency process and therefore might be the simplest way of achieving international agreement on resolving the financial distress of G-SIFIs (as long as there is global agreement on resolution mechanisms for SIALs). 
As an illustration of why such a bottom-up approach is needed, we note that the current financial legislation proposals are completely silent on how to reform the repo market in which financial firms borrow secured at a short-term maturity with rights for repo financiers in cases of most underlying collateral to be exempt from bankruptcy and liquidate the collateral in case of borrower's default. We believe this omission is a mistake in light of the systemic nature of the repo market and its structural weaknesses. As we mentioned, unlike the liquidity risk that unsecured financing may become unavailable to a firm, the liquidity risk that secured repo financing may become unavailable to a firm is inherently a systemic risk: The markets for the repo securities may become illiquid precisely when a large part of the financial sector is experiencing undercapitalization or funding stress.

Unless this systemic liquidity risk of the repo market is resolved, the risk of a run on the repo market will remain. Our proposed solution is to set up a "repo resolution authority" that maintains liquidity for repo markets in case of defaults and takes on the role of orderly liquidation of collateral but controls its credit risk through ex ante restrictions on qualifying collateral, qualifying repo financiers, concentration limits, and minimum haircuts. Such a resolution mechanism addresses the externality of systemic risk of repo contracts on risky and potentially illiquid collaterals. And such a mechanism can be exercised without overly compromising market discipline, market liquidity, or taxpayer funds.

Interestingly, the Federal Reserve, the Bank of England, and the European Central Bank set up many facilities to halt a total financial collapse during the heyday of the ongoing global financial crisis. These have invariably been facilities set up for systemically important assets and liabilities. For instance, the Federal Reserve's Term Auction Facility, which auctioned term loans to depository institutions, and its Primary Dealer Credit Facility, which provided overnight loans to primary dealers, were to lengthen the maturity of their systemically important liabilities. The Federal Reserve's Asset-Backed Commercial Paper Money Market Mutual Fund Liquidity Facility and Term Asset-Backed Securities Loan Facility were to provide liquidity directly to borrowers holding systemically important assets. Stated differently, financial regulators around the globe were forced in the midst of a crisis to act on 
systemically important assets and liabilities, rather than just on individual financial institutions holding them. Our key recommendation is to recognize the need for such action ahead of time and build the essential infrastructure to ensure that excessive risk taking is discouraged and markets know that regulators have an orderly resolution plan.

Finally, although we have focused on the U.S. repo markets, our discussion and proposed reforms apply to other countries as well. Repo markets exist around the globe, from China to Japan to Hungary to Turkey, to name but a few countries, although their histories are much shorter and their sizes much smaller than that of the U.S. repo market. Many emerging countries' repo markets date back to the early 1990s. The largest repo market outside the United States is the European repo market, which was established with the introduction of the euro in 1999 and stood at €5.6 trillion based on the amount outstanding on December 9, 2009 (according to the survey conducted by the International Capital Market Association with fifty-three financial institutions located in fourteen European countries, as well as the United States and Japan). The European market is the only repo market outside the United States where potentially illiquid financial assets are used as repo collateral, and therefore our proposed reforms are also relevant to the European repo market. In other repo markets, the repo collateral generally represents government bonds issued by the sovereign states, so that in these markets, the repo financiers do not appear to run a substantial risk of being forced to sell their collateral in illiquid markets in the event of financial crises. This may change however, if potentially illiquid collateral were to become acceptable in repo transactions in these countries. Indeed, when sovereign credit risk is an issue, even the repo markets for government bonds may be vulnerable.

At any rate, leaving the repo markets out of the discussion of financial reforms is not an alternative; if these markets are not reformed and their participants not made to internalize the risk that large quantities of underlying repo collateral could be put up for liquidation in an illiquid market, then runs on the repo market will occur in the future, potentially leading to new systemic crises, in spite of the huge regulatory apparatus being built around financial firms on other fronts and markets. 


\section{References}

Acharya, V. V., B. Adler, and M. Richardson. 2011. "A Proposal to Resolve the Distress of Large and Complex Financial Institutions." New York University, Stern School of Business Working Paper.

Acharya, V. V., B. Adler, M. Richardson, and N. Roubini. 2010. "Resolution Authority." In Regulating Wall Street, The DoddFrank Act and the New Architecture of Global Finance, ed. V. V. Acharya, T. F. Cooley, M. Richardson, and I. Walter, chapter 8. New York University Stern School of Business and John Wiley \& Sons.

Acharya, V. V., T. F. Cooley, M. Richardson, and I. Walter, ed. 2011. Dodd-Frank: One Year On. VoxEu.org eBook. Available at http://www.voxeu.org/content/dodd-frank-one-year.

Acharya, V. V., and A. Krishnamurthy. 2010. "Why Bankers Must Bear the Risk of 'Too Safe to Fail' Assets." Financial Times, March 17.

Acharya, V. V., and T. S. Öncü. 2010. "The Repurchase Agreement (Repo) Market." In Regulating Wall Street, The Dodd-Frank Act and the New Architecture of Global Finance, ed. V. V. Acharya, T. F. Cooley, M. Richardson, and I. Walter, chapter 11. New York University Stern School of Business and John Wiley \& Sons.

Acharya, V. V., L. H. Pedersen, T. Philippon, and M. Richardson. 2010. "Measuring Systemic Risk." New York University, Stern School of Business Working Paper.

Acharya, V. V., and M. Richardson, ed. 2009. Restoring Financial Stability: How to Repair a Failed System. New York University Stern School of Business and John Wiley \& Sons.

Acharya, V. V., P. Schnabl, and G. Suarez. 2009. "Securitization

Without Risk Transfer." Forthcoming in Journal of Financial Economics.

Bernanke, B. S. 2008. "Liquidity Provision by the Federal Reserve."

Remarks (via videoconference) to the Risk Transfer Mechanisms and Financial Stability Workshop at the Bank for International Settlements, Basel, Switzerland, May 29. 
Bliss, R., and G. Kaufman. 2011. "Resolving Large, Insolvent Complex Financial Institutions: A Better Way." The Banking Law Journal (April): 339-63.

Calomiris, C. W., and E. N. White. 1994. "The Origins of Federal Deposit Insurance." In The Regulated Economy, ed. C. Goldin and G. D. Libecop. Chicago: University of Chicago Press.

Cohan, W. D. 2009. House of Cards: A Tale of Hubris and Wretched Excess on Wall Street. New York: Knopf Doubleday.

Copeland, A., I. Davis, E. LeSuer, and A. Martin. 2012. "Mapping and Sizing the U.S. Repo Market." Liberty Street Economics (Federal Reserve Bank of New York blog) June 25, 2012.

Copeland, A., A. Martin, and M. W. Walker. 2010. "The Tri-Party Repo Market Before the 2010 Reforms." Federal Reserve Bank of New York Working Paper.

Edwards, F., and E. Morrison. 2004. "Derivatives and the Bankruptcy Code: Why the Special Treatment?" Columbia Law and Economics Research Paper No. 258.

Faubus, B. 2010. "Narrowing the Bankruptcy Safe Harbor for Derivatives to Combat Systemic Risk." Duke Law Journal 59 (4): 801-42.

Federal Deposit Insurance Corporation. 2011. "The Meeting of the Systemic Resolution Advisory Committee of the Federal Deposit Insurance Corporation." Minutes of a meeting held in the FDIC Building, Washington, DC, June 21.

Federal Reserve Bank of New York. 2010. "Tri-Party Repo Infrastructure Reform." White Paper. May 17. Available at http:// www.newyorkfed.org/banking/nyfrb_triparty_whitepaper.pdf.

Fleming, M., and K. D. Garbade. 2003. "The Repurchase Agreement Refined: GCF Repos ${ }^{\circledR}$." Current Issues in Economics and Finance (Federal Reserve Bank of New York) 9 (6): 1-7.

Garbade, K. D. 2006. "The Evolution of Repo Contracting Conventions in the 1980s." Economic Policy Review (Federal Reserve Bank of New York) (May): 27-42.

Gorton, G. 2009. "Slapped in the Face by the Invisible Hand: Banking and the Panic of 2007." Presented at the Federal Reserve Bank of Atlanta's 2009 Financial Markets Conference: Financial Innovation and Crisis, May 11-13.

Gorton, G., and A. Metrick. 2009a. "Haircuts." Yale ICF Working Paper No. 09-15. 
. 2009b. "Securitized Banking and Run on the Repo." Yale ICF Working Paper No. 09-14.

_. 2010. "Regulating the Shadow Banking System." Yale University Working Paper.

Graeber, D. 2011. Debt, The First 5,000 Years. Brooklyn, New York: Melville House.

Jackson, T. H. 2009. "A Proposal for the Use of Bankruptcy to Resolve Financial Institutions." In Ending Government Bailouts as We Know Them, ed. K. E. Scott, G. P. Shultz, and J. B. Taylor, chapter 11F. Hoover Press.

Kaufman, G. G. 2004. "Depositor Liquidity and Loss-Sharing in Bank Failure Resolutions." Contemporary Economic Policy 22 (2): 237-49.

Kaufman, G. G., and K. E. Scott. 2003. "What Is Systemic Risk, and Do Bank Regulators Retard or Contribute to It?" The Independent Review 7 (3): 371-91.

Krishnamurthy, A., S. Nagel, and D. Orlov. 2011. "Sizing Up Repo." Working Paper, Northwestern University.

Miller, H. 2009. "Too Big to Fail: The Role of Bankruptcy and Antitrust Law in Financial Regulation Reform." Testimony before the Subcommittee on Commercial and Administrative Law of the House of Representatives Committee on the Judiciary, October 22.

Olson, J. S. 1988. Saving Capitalism. Princeton, NJ: Princeton University Press.

Perotti, E. 2010. "Systemic Liquidity Risk and Bankruptcy Exceptions." CPER Policy Insight No. 52 (October).

Reinhart, C. M., and K. S. Rogoff. 2009. This Time Is Different: Eight Centuries of Financial Folly. Princeton, NJ, and Oxford: Princeton University Press.

Roe, M. J. 2009. "End Bankruptcy Priority for Derivatives, Repos and Swaps." Financial Times, December 16.

—. 2010. "Bankruptcy's Financial Crisis Accelerator: The Derivatives Players' Priorities in Chapter 11." Harvard Public Law Working Paper No. 10-17.

Tuckman, B. 2010. "Amending Safe Harbors to Reduce Systemic Risk in OTC Derivative Markets." CFS Policy Paper. -. 2012a. "Flash: Tri-Party Repo Infrastructure Reform." CFS Policy Paper. 
- 2012b. "How to Contain a Financial Crisis Without Bailouts." Forbes.com, March 22.

Upham, C., and E. Lamke. 1934. Closed and Distressed Banks. Washington, DC: Brookings Institution.

Willis, H. P., and J. M. Chapman. 1934. The Banking Situation. New York: Columbia University Press. 